\title{
Clinical practice guidelines for suctioning the airway of the intubated and nonintubated patient
}

\author{
Dina Brooks BScPT MSc PhD ${ }^{1^{*}}$, Cathy M Anderson BSc BHScPT MSc ${ }^{2,3^{*}}$, \\ Margaret A Carter BSc RRCP RRT ${ }^{4^{*}}$, Laurie A Downes BScPT MSc ${ }^{5^{*}}$, \\ Sean P Keenan MD MSc FRCPC ${ }^{2^{*}}$, Carol J Kelsey BScPT MSc ${ }^{1^{*}}$, Janet B Lacy BScPT MSc ${ }^{1^{*}}$ \\ ${ }^{1}$ Department of Physical Therapy, University of Toronto, Toronto; ${ }^{2}$ London Health Sciences \\ Centre, London; ${ }^{3}$ Department of Physical Therapy, University of Western Ontario, London; \\ ${ }^{4}$ College of Respiratory Therapists of Ontario, Toronto; ${ }^{5}$ College of Physiotherapists of Ontario, \\ Toronto, Ontario
}

\begin{abstract}
D Brooks, CM Anderson, MA Carter, et al. Clinical practice guidelines for suctioning the airway of the intubated and nonintubated patient. Can Respir J 2000; 8(3):163-181.
\end{abstract}

OBJECTIVE: To provide physicians, physiotherapists, nurses and respiratory therapists with guidelines for the application of airway suctioning.

DESIGN: This clinical practice guideline was developed using the model by Browman and colleagues. A working group of representatives from four professional colleges (nurses, physicians and surgeons, physiotherapists and respiratory therapists) and research experts was formed to conduct a systematic review, develop evidence-based recommendations and generate clinical practice guidelines. MEDLINE (1966 to 1998), CINAHL (1982 to 1997) and EMBASE (1974 to 1996) as well as the reference lists of identified articles were searched. Inclusion of articles was determined by at least two group members, and studies were classified according to type. Randomized, controlled; randomized; and nonrandomized crossover and comparative cohort trials were grouped by type of intervention and population for use in the development of recommendations. Other observational and animal studies dealing with adverse effects of suctioning were included in the review but were not used in the development of recommendations. Input on the evidencebased recommendations was sought and incorporated from members of all four professions and from experts on content and methodology.

SETTING: Any setting (hospital or home) where suctioning is performed.

POPULATION: Intubated and nonintubated adults, infants and children.

RESULTS AND CONCLUSIONS: An attempt was made to develop recommendations in each of the subcategories of suctioning techniques addressed by at least one study. In some subcategories, definite recommendations were made (13 in adults, and three in children and infants); in other subcategories, insufficient evidence precluded recommendations. The recommendations addressed the following aspects of suctioning: preoxygenation, hyperinflation, insufflation, hyperoxygenation, hyperventilation, saline instillation, adaptor use, medication use, open and closed systems, and various types of catheters.

Key Words: Adult; Clinical practice guidelines; Intubation; Pediatric; Suction

Pour le résumé, voir page suivante

* Members of the Interdisciplinary Working Group

Correspondence and reprints: Dr D Brooks, Department of Physical Therapy, University of Toronto, 256 McCaul Street, Toronto, Ontario M5T 1X5. Telephone 416-978-1739, fax 416-978-4363, e-mail dina.brooks@ utoronto.ca 


\section{Directives de pratiques cliniques pour l'aspiration des voies respiratoires du patient intubé ou non intubé}

OBJECTIF : Offrir aux médecins, physiothérapeutes, infirmières et inhalothérapeutes des directives techniques pour l'aspiration des voies respiratoires.

MODÈLE : Ces directives de pratique clinique ont été élaborées à partir du modèle de Browman et coll. Un groupe de travail représentant les quatre collèges professionnels (infirmières, médecins et chirurgiens, physiothérapeutes et inhalothérapeutes) et des experts en recherche a été formé pour procéder à une analyse systématique, développer des recommandations fondées sur des preuves et rédiger des directives de pratique clinique. Les réseaux MEDLINE (1966 à 1998), CINAHL (1982 à 1997) et EMBASE (1974 à 1996), de même que des listes d'articles scientifiques fournis en référence ont été passés en revue. L'inclusion des articles a été déterminée par au moins deux membres du groupe et les études ont été classées selon leur type. Des essais randomisés et contrôlés, des essais randomisés et des essais comparatifs transversaux non randomisés portant sur des cohortes ont été regroupés selon le type d'intervention et selon la population à qui étaient destinées les recommandations. D'autres études d'observation et études animales portant sur les effets indésirables de l'aspiration ont été incluses dans l'analyse, mais n'ont pas servi à l'élaboration des recommandations. Des membres des quatre professions et des experts du contenu et de la méthodologie ont été mis à contribution lors de la préparation et de la rédaction de ces recommandations fondées sur des preuves.

CONTEXTE : Tout contexte (hôpital ou domicile) où l'on effectue l'aspiration des voies respiratoires.

POPULATION : Adultes, nourrissons et enfants, intubés et non intubés.

RÉSULTATS ET CONCLUSIONS : On a tenté de développer des recommandations pour chacune des sous-catégories de techniques d'aspiration mentionnée dans au moins une étude. Dans certaines sous-catégories, des recommandations précises ont été faites (13 pour les adultes et 3 pour les enfants et les nourrissons). Dans d'autres sous-catégories, le manque de preuves a empêché la préparation de recommandations. Ces recommandations visaient les aspects suivants de l'aspiration : pré-oxygénation, hyperinflation, insufflation, hyperoxygénation, hyperventilation, instillation de sérum physiologique, utilisation d'un adaptateur, utilisation de médicaments, systèmes ouverts et fermés et divers types de cathéters.
$\mathrm{U}$ nder the Regulated Health Professions Act, enacted in Ontario in 1994, high risk procedures are designated as 'controlled acts.' Only certain identified professionals in the legislation are authorized to perform these controlled acts on clients. In Ontario, nurses, physicians, physiotherapists and respiratory therapists are authorized to perform the controlled act of suctioning. Each professional college regulates its members concerning the performance of the controlled act.

To perform suctioning, a catheter or device is inserted via the nasopharynx or oropharynx, or through a nasopharyngeal or an oropharyngeal airway, or an endotracheal or tracheostomy tube. Although suctioning is a common technique employed with critically ill patients, rehabilitation patients and patients at home, controversy exists over the beneficial and harmful effects of the procedure.

A survey of practitioners in Ontario revealed a large variation in practice in the application of oropharyngeal and tracheal suctioning and procedures such as hyperoxygenation, hyperinflation and saline instillation (1). These variations existed despite reports of locally developed guidelines and policies regarding suctioning practices (1), several published review articles (2-13) and one clinical practice guideline (CPG) on this topic (14). Neither the review articles nor the published CPG used a rigorous critical appraisal procedure or a clear explicit process for consensus or investigation and assessment of the evidence.

The goal of the interdisciplinary working group was to answer the following questions, using a model published by the Ontario Cancer Treatment Practice Guidelines Initiative CPG group (15).

What are the clinical indications and precautions for suctioning, and what is the evidence to support the procedures of tracheal and pharyngeal suctioning by health professionals for patients of any age to prevent upper airway obstruction and to clear secretions?

What are the methods, techniques and monitoring tools that optimize benefits and reduce complications when suctioning is performed on patients of all ages who are intubated, nonintubated or tracheotomized?

\section{MATERIALS AND METHODS}

Electronic database searches included MEDLINE (1966 to 1998), EMBASE (1974 to 1996) and CINAHL (1982 to 1997). Key words used for the searches were 'trachea', 'pharynx', 'tracheostomy', 'suction', 'artificial airway', 'inflation' and 'endotracheal'. All searches were limited to English. Printouts from these searches, including title, authors, journal and abstract (where available) were reviewed by at least two group members. Initially, broad, subject-related criteria were used to determine which articles would be retrieved for further review. Retrieved articles consisted of reviews, guidelines, studies of any design and any article for which the reference list was thought to be useful. The Cochrane Database was searched for relevant reviews; none were found.

At least two members of the working group reviewed each article retrieved and agreed on whether it should be included or excluded from further analysis. Excluded articles consisted of those that used interventions not relevant to the questions, that reported on a diagnostic test or that were reviews, guidelines, protocols or other descriptive articles. Included articles were randomized, controlled trials; randomized and nonrandomized crossover trials; comparative cohort studies; case series; and animal studies. The epidemiologist's decision to exclude any article was ratified by at 
least one clinician. The reference lists of both included and excluded studies were reviewed for identification of other relevant articles. Only abstracts with sufficient information to allow judgment of methodology and interpretation of data were included. No attempts were made to locate unpublished data or to contact authors for information that was absent from the published article.

A data collection form was designed by the group. Data extraction was first completed by the clinical epidemiologist, and included information on the study type, allocation methods, subject inclusion/exclusion criteria, when the study was conducted, adequacy of follow-up, comparison of baseline characteristics, specific interventions and outcome measures. At least two group members then reviewed each article and the previously extracted information on the collection form. Additional data extraction involved determining whether the outcome measures of physiological status were appropriate, valid and reliable; setting priorities when there were multiple outcomes reported; and abstracting results. Detailed summaries of each article were composed. The working group used these summaries to formulate recommendations. Modified versions of the data tables have been included in the 'Discussion' section of this paper.

To develop evidence-based recommendations, we focused primarily on randomized, controlled trials (RCTs) and comparative cohort studies. Many of the studies used a crossover design. If the authors did not specify randomization of the order of interventions, the study was assumed to be nonrandomized. Because many studies were not randomized and most could not be adequately double-blinded, no formal quality assessment tool was used. No attempt was made to use a formalized system to rate the levels of evidence; however, the number and types of studies were summarized in each category. Due to the heterogeneity in patient populations, differences in the intervention techniques and outcomes measured, and other methodological issues, no meta-analyses were performed.

Case series and animal studies were not considered when making evidence-based recommendations; however, they were reviewed to gain insight into the potentially harmful effects of suctioning. For ethical reasons, it is not possible to use RCTs and comparative cohort studies to examine the possible hazardous effects of suctioning. Once the evidencebased recommendations were formulated, we ensured that none of the recommended approaches had been shown to cause harm in either case series or animal studies.

We generated a full, detailed 'technical report' and a short summary of the recommendations (less than five pages). We then sought input on the short summary from 165 clinicians (84 physical therapists, 33 respiratory therapists and 48 nurses). In addition, the full technical report was sent to four clinical experts representing each of the professions and three methodological experts (with recognized expertise in guideline development, systematic overview and/or meta-analysis). Standardized forms were used to seek feedback. The working group considered all feedback, and modifications were made for clarification of the document.

\begin{tabular}{lc} 
TABLE 1 \\
Number of included and excluded articles, the types of \\
included ones and the reasons for exclusion \\
\hline \multicolumn{3}{c}{$\mathbf{3 1 7}$ studies retrieved } \\
\begin{tabular}{cc}
$\mathbf{1 6 2}$ articles included & $\mathbf{1 5 5}$ articles excluded \\
\hline 59 randomized, controlled or & $\mathbf{4 3}$ interventions or outcomes \\
crossover trials & unrelated to suctioning \\
28 nonrandomized crossovers & 16 related to diagnostic tests \\
or comparative cohorts & 50 reviews or descriptive articles \\
49 observational studies of & 31 observational studies not \\
precautions & dealing with precautions \\
26 animal or test-lung models & Five animal or test models \\
& unrelated to suctioning \\
& Three no data \\
& Seven other
\end{tabular}
\end{tabular}

\section{RESULTS}

From the combined searches, 317 articles were retrieved. Of these, 162 were included and 155 were excluded. The number of articles excluded or included and the reasons for this are presented in Table 1.

Only one study dealt specifically with the first question, ie, the indication for suctioning. The remaining 161 studies were related to the second question (ie, "What are the methods, techniques and monitoring tools that optimize benefits and reduce complications when suctioning patients of all ages who are intubated, nonintubated or tracheotomized?"), and were either randomized, controlled, crossover or comparative cohort in design. Studies were separated into two sections: infants and children $(n=23)$, and adults $(n=139)$. There were 13 recommendations for adults and three for infants and children. For the infants and children section, articles were categorized according to subpopulation. For the adult population, the studies were categorized on the basis of the technique used. While many studies lacked important outcomes, recommendations were only made for the outcomes reported.

Input on the evidence-based recommendations was received from 103 clinicians (57 physical therapists, 19 respiratory therapists and 27 nurses), and from all seven clinical and methodological experts. The working group discussed all input in detail and incorporated the changes where it was deemed appropriate by the entire working group. Although the feedback did not result in fundamental changes to the recommendations, the document was modified to improve its clarity and readability.

\section{DISCUSSION}

Summaries and recommendations in infants and children: The studies in pediatrics were categorized according to subpopulation: nonintubated neonates with and without meconium aspiration syndrome (MAS), intubated preterm and full-term neonates, and intubated infants and children. Table 2 includes information about the studies that was used to formulate the following recommendations. 
TABLE 2

Summary of studies in children and infants

\begin{tabular}{|c|c|c|c|c|c|c|}
\hline $\begin{array}{l}\text { Author, year } \\
\text { (reference) }\end{array}$ & Population & Treatment allocation & $\begin{array}{c}\text { First outcome (primary } \\
\text { study outcome) }\end{array}$ & $\mathbf{P}$ & $\begin{array}{l}\text { Second outcome } \\
\text { (could also be } \\
\text { primary) }\end{array}$ & $\mathbf{P}$ \\
\hline $\begin{array}{l}\text { Cohen-Addad et } \\
\text { al, } 1987(16)\end{array}$ & $\begin{array}{l}\text { Deliveries with } \\
\text { meconium staining, } \\
\text { not intubated }(n=60)\end{array}$ & $\begin{array}{l}\text { Type of catheter } \\
\text { RCT } \\
\text { 1. Intrapartum suctioning, } \\
\text { syringe (bulb) } \\
\text { 2. Intrapartum suctioning, } \\
\text { De Lee catheter }\end{array}$ & $\begin{array}{l}\text { Incidence of MAS } \\
\text { Overall: } 7 / 60(11.7 \%) \\
\text { 3/31 De Lee }(9.7 \%) \\
\text { 4/29 Bulb }(13.8 \%)\end{array}$ & NS & $\begin{array}{l}\text { Meconium recovered } \\
\text { means } \\
\text { Bulb: } 0.24 \mathrm{~mL} \\
\text { De Lee: } 0.16 \mathrm{~mL}\end{array}$ & NS \\
\hline $\begin{array}{l}\text { Locus et al, } \\
1990(17)\end{array}$ & $\begin{array}{l}\text { Moderate or thick } \\
\text { meconium }(n=107)\end{array}$ & $\begin{array}{l}\text { Type of suction device } \\
\text { Cohort } \\
\text { 1. Bulb suction } \\
\text { 2. De Lee suction }\end{array}$ & $\begin{array}{l}\text { Meconium suctioned from } \\
\text { below vocal cord }(0.22 \\
\text { and } 0.24 \mathrm{~mL})\end{array}$ & 0.22 & $\begin{array}{l}\text { MAS or death } \\
\text { NS }\end{array}$ & NS \\
\hline $\begin{array}{l}\text { Daga et al, } \\
1994(18)\end{array}$ & $\begin{array}{l}\text { Meconium in utero, } \\
\text { not intubated }(n=49)\end{array}$ & $\begin{array}{l}\text { Oropharyngeal versus } \\
\text { tracheal } \\
\text { RCT } \\
\text { 1. OP } \\
\text { 2. OP + tracheal suctioning }\end{array}$ & $\begin{array}{l}\text { Incidence of death } \\
0 / 23 \text { in } 1 \\
1 / 26 \text { in } 2 \\
\text { Incidence of hypoxic ischemic } \\
\text { encephalopathy } \\
0 / 23 \text { in } 1 \\
1 / 26 \text { in } 2\end{array}$ & NS & $\begin{array}{l}\text { Pneumothorax } \\
2 / 23 \text { in } 1 \\
1 / 26 \text { in } 2 \\
\text { Convulsions } \\
1 / 23 \text { in } 1 \\
3 / 26 \text { in } 2\end{array}$ & NS \\
\hline $\begin{array}{l}\text { Linder et al, } \\
1988 \text { (19) }\end{array}$ & $\begin{array}{l}\text { Newborn with 'normal' } \\
\text { vaginal delivery, } \\
\text { meconium stained } \\
(n=572)\end{array}$ & $\begin{array}{l}\text { Indication-tracheal } \\
\text { Cohort } \\
\text { 1. Tracheal suction } \\
\text { 2. OP }\end{array}$ & $\begin{array}{l}\text { Particulate/pea soup amniotic } \\
\text { fluid } \\
40 \% \text { in } 1 \text { and } 35 \% \text { in } 2 \\
\text { Respiratory complications (MAS } \\
\text { and laryngeal stridor): } \\
\text { Group 1, 6/308 } \\
\text { Group 2, 0/264 }\end{array}$ & $P<0.025$ & No death in either group & \\
\hline $\begin{array}{l}\text { Estol et al, } \\
1992(20)\end{array}$ & $\begin{array}{l}\text { Clear amniotic fluid, } \\
\text { not intubated }(n=40)\end{array}$ & $\begin{array}{l}\text { Indication-pharyngeal } \\
\text { Cohort } \\
\text { 1. Suction } \\
\text { 2. No suction }\end{array}$ & $\begin{array}{l}\text { Expiratory and inspiratory } \\
\text { dynamic compliance, NS }\end{array}$ & NS & $\begin{array}{l}\text { Inspiratory and expiratory } \\
\text { resistance, NS }\end{array}$ & NS \\
\hline $\begin{array}{l}\text { Barnes et al, } \\
1981(21)\end{array}$ & $\begin{array}{l}\text { Respiratory distress, } \\
\text { intubated and } \\
\text { mechanically } \\
\text { ventilated }(n=32)\end{array}$ & $\begin{array}{l}\text { Hyperinflation } \\
\text { RC } \\
\text { 1. CPT, bagging, suction, } \\
\text { bagging, suction } \\
\text { 2. CPT, suction, bagging, } \\
\text { suction, bagging } \\
\text { 3. CPT, bagging, suction, } \\
\text { bagging, suction, bagging, } \\
\text { hyperinflation }\end{array}$ & $\mathrm{TcPO}_{2}$ values, $\mathrm{NS}$ & NS & $\begin{array}{l}\text { Group } 2 \text { hypoxia was } \\
\text { minimized, hyperoxia } \\
\text { was less than in group } 3, \\
\text { and stability and recovery } \\
\text { times were less than in } \\
\text { groups } 1 \text { and } 3\end{array}$ & $\begin{array}{l}\text { Not } \\
\text { stated }\end{array}$ \\
\hline $\begin{array}{l}\text { Cunningham et } \\
\text { al, } 1984(22)\end{array}$ & $\begin{array}{l}\text { Premature babies } \\
\text { (RDS and non } \\
\text { RDS), intubated, } \\
\text { ventilated }(n=8)\end{array}$ & $\begin{array}{l}\text { Hyperoxygenation and } \\
\text { hyperventilation } \\
\mathrm{RC} \\
1 . \mathrm{O}_{2} 10 \% \text { increase, } \\
5 \text { breaths } / 15 \mathrm{~s} \\
2 . \mathrm{O}_{2} 20 \% \text { increase, } \\
5 \text { breaths } / 15 \mathrm{~s} \\
3 . \mathrm{O}_{2} 10 \% \text { increase, } \\
10 \text { breaths/30 s } \\
4.20 \% \text { increase, } \\
10 \text { breaths } / 30 \mathrm{~s}\end{array}$ & $\begin{array}{l}\mathrm{Tc} P \mathrm{O}_{2} \\
\mathrm{RDS} \text { babies had a decrease in } \\
\mathrm{TcPO}_{2} \text { in all groups } \\
\text { Non } \mathrm{RDS} \text { babies in conditions } 1 \\
\text { and } 3 \text { had slight fluctuation in } \\
\mathrm{O}_{2} \text {. With conditions } 2 \text { and } 4 \text {, } \\
\mathrm{TcPO}_{2} \text { rose with first inflation } \\
\text { Condition } 1 \text { resulted in more } \\
\text { hypoxic events than } 2,3 \\
\text { and } 4\end{array}$ & $\begin{array}{c}\mathrm{P}<0.02 \\
\text { No } P \text { given }\end{array}$ & $\begin{array}{l}\text { HR decrease was the } \\
\text { same in all protocols but } \\
\text { bradycardia was greatest } \\
\text { in condition } 1 \text { and least } \\
\text { in } 4\end{array}$ & No stats \\
\hline $\begin{array}{l}\text { Walsh et al, } \\
1987 \text { (23) }\end{array}$ & $\begin{array}{l}\text { Preterm with RDS, } \\
\text { intubated and } \\
\text { ventilated }(n=21)\end{array}$ & $\begin{array}{l}\text { Preoxygenation } \\
\mathrm{RC} \\
\text { 1. Standard hygiene } \\
\text { 2. } \mathrm{FiO}_{2} \text { increased until } \mathrm{Tc}_{\mathrm{C}} \mathrm{PO}_{2} \\
\text { above } 90\end{array}$ & $\begin{array}{l}\text { Significantly greater decrease in } \\
\mathrm{TcPO}_{2} \text { in } 1(35 \% \text { to } 51 \%) \\
\text { than in } 2(0 \% \text { to } 9 \%)\end{array}$ & $P \leq 0.006$ & $\begin{array}{l}\text { Mean recovery time } \\
4.9 \text { min in } 1 \\
2.8 \min \text { in } 2 \\
\text { Significantly longer } \\
\text { without } \mathrm{O}_{2}\end{array}$ & $P<0.0001$ \\
\hline $\begin{array}{l}\text { Cabal et al, } \\
1984(24)\end{array}$ & $\begin{array}{l}\text { Premature, intubated } \\
\text { and ventilated } \\
(n=10)\end{array}$ & $\begin{array}{l}\text { Preoxygenation } \\
\text { Cohort } \\
\text { 1. Preoxygenation } \\
\text { 2. No preoxygenation }\end{array}$ & $\begin{array}{l}\mathrm{PaO}_{2} \text { postsuction values } \\
50 \mathrm{mmHg} \text { in } 1 \\
63 \mathrm{mmHg} \text { in } 2\end{array}$ & $P<0.02$ & $\begin{array}{l}\text { Peak HR dropped to } \\
89 \text { beats/min in } 2 \text {, } \\
112 \text { beats/min in } 1\end{array}$ & $P<0.02$ \\
\hline $\begin{array}{l}\text { Skov et al, } \\
1992(25)\end{array}$ & $\begin{array}{l}\text { Intubated and } \\
\text { ventilated newborns, } \\
\text { gestational age of } 25 \\
\text { to } 40 \text { weeks }\end{array}$ & $\begin{array}{l}\text { Preoxygenation } \\
\text { Cohort } \\
\text { 1. First time suction with } \\
\text { preoxygenation, second time } \\
\text { without } \\
\text { 2. Had preoxygenation before } \\
\text { second suction }\end{array}$ & $\begin{array}{l}\text { Hemoglobin oxygenation index } \\
\text { and } \mathrm{SaO}_{2} \\
\text { Preoxygenation reduced the } \\
\text { decrease in both }\end{array}$ & $P<0.05$ & $\begin{array}{l}\text { No differences between } \\
\text { groups in mean arterial } \\
\text { blood pressure and } \\
\text { cerebral hemoglobin } \\
\text { concentration }\end{array}$ & NS \\
\hline $\begin{array}{l}\text { Wilson et al, } \\
1991 \text { (26) }\end{array}$ & $\begin{array}{l}\text { Premature with RDS, } \\
\text { intubated and } \\
\text { ventilated }(n=97)\end{array}$ & $\begin{array}{l}\text { Suction frequency } \\
\text { RCT } \\
\text { 1. Suction } q 6 \mathrm{~h} \\
\text { 2. Suction } \mathrm{q} 12 \mathrm{~h}\end{array}$ & $\begin{array}{l}\text { Median time on ventilation } \\
28 \mathrm{~h} \text { in } 1 \\
39 \mathrm{~h} \text { in } 2\end{array}$ & NS & $\begin{array}{l}\text { Death } \\
\begin{array}{l}14 \% \text { in } 1 \\
21 \% \text { in } 2\end{array}\end{array}$ & NS \\
\hline $\begin{array}{l}\text { Fanconi and } \\
\text { Duc, } 1987 \\
\text { (27) }\end{array}$ & $\begin{array}{l}\text { Prematures intubated, } \\
\text { paralyzed, ventilated } \\
(n=28)\end{array}$ & $\begin{array}{l}\text { Muscle relaxant } \\
\text { Cohort } \\
\text { 1. With muscle paralysis } \\
\text { 2. Without muscle paralysis }\end{array}$ & $\begin{array}{l}\text { ICP increase during suctioning } \\
\text { when not paralyzed ( } 13.7 \text { to } \\
15.8 \text { in } 1 \text { and } 12.5 \text { to } 28.5 \text { in } 2)\end{array}$ & $P<0.01$ & $\begin{array}{l}\text { Slight increase in } \mathrm{BP} \text { with } \\
\text { and without paralysis }\end{array}$ & NS \\
\hline
\end{tabular}


TABLE 2 (continued)

\begin{tabular}{|c|c|c|c|c|c|c|}
\hline $\begin{array}{l}\text { Author, year } \\
\text { (reference) }\end{array}$ & Population & Treatment allocation & $\begin{array}{l}\text { First outcome (primary } \\
\text { study outcome) }\end{array}$ & $\mathbf{P}$ & $\begin{array}{l}\text { Second outcome } \\
\text { (could also be } \\
\text { primary) }\end{array}$ & $\mathbf{P}$ \\
\hline $\begin{array}{r}\text { Saarenmaa et } \\
\text { al, } 1996(28)\end{array}$ & $\begin{array}{l}\text { Ventilated, intubated } \\
\text { newborns, } \\
\text { gestational age of } \\
\text { 29-36 weeks }(n=10)\end{array}$ & $\begin{array}{l}\text { Sedation } \\
\text { RC } \\
\text { 1. Saline } \\
\begin{array}{ll}\text { 2. Alfentanil } 10 \mathrm{~g} / \mathrm{kg} \mathrm{IV} \\
\text { 3. Alfentanil } 20 \mathrm{~g} / \mathrm{kg}\end{array}\end{array}$ & $\begin{array}{l}\text { Pain and behavioural scale less } \\
\text { in group } 3 \text {, but muscle rigidity } \\
\text { frequent }\end{array}$ & $P=0.031$ & & \\
\hline $\begin{array}{l}\text { Pokela, } 1994 \\
\text { (29) }\end{array}$ & $\begin{array}{l}\text { Preterm or term RDS, } \\
\text { less than one week } \\
\text { old }(n=84)\end{array}$ & $\begin{array}{l}\text { Sedation } \\
\text { RC } \\
\text { 1. Sedation (meperidine, } \\
1 \mathrm{mg} / \mathrm{kg} \text { ) } \\
\text { 2. No sedation (saline) }\end{array}$ & $\begin{array}{l}\text { Longer duration of hypoxemia } \\
\text { in } 2 \\
\text { ( } 44 \mathrm{~s} \text { versus } 29 \mathrm{~s})\end{array}$ & $P=0.002$ & No difference in $\mathrm{BP}$ or $\mathrm{HR}$ & NS \\
\hline $\begin{array}{l}\text { Ninan et al, } \\
1986(30)\end{array}$ & $\begin{array}{l}\text { Respiratory failure, } \\
\text { preterm, RDS, } \\
\text { ventilation } \\
(n=7)\end{array}$ & $\begin{array}{l}\text { Sedation } \\
\text { Cohort } \\
\text { 1. Sedation (phenobarbital or } \\
\text { chloral hydrate) } \\
\text { 2. No sedation }\end{array}$ & Significant blunting of ICP in 1 & P 0.01 & $\begin{array}{l}\text { Mean arterial and cerebral } \\
\text { perfusion pressures } \\
\text { blunted in } 1\end{array}$ & $\begin{array}{ll}P & 0.01 \\
P & 0.05\end{array}$ \\
\hline $\begin{array}{l}\text { Beeram and } \\
\text { Dhanireddy, } \\
1992(32)\end{array}$ & $\begin{array}{l}\text { RDS or MAS, } \\
\text { intubated and } \\
\text { ventilated }(n=18)\end{array}$ & $\begin{array}{l}\text { Instillation } \\
\text { RC } \\
\text { 1. Suction no saline } \\
\text { 2. Suction + saline }(1.0 \mathrm{~mL})\end{array}$ & $\begin{array}{l}\text { Dynamic compliance: no } \\
\text { change in RDS or MAS } \\
\text { Airway resistance: no change in } \\
\text { RDS but decrease in MAS } \\
\text { with saline }\end{array}$ & $\begin{array}{l}\text { NS } \\
\text { RDS: NS } \\
\text { MAS: P } 0.05\end{array}$ & $\begin{array}{l}\text { In RDS, significant drop in } \\
\mathrm{SaO}_{2} \text { with saline; in } \\
\mathrm{MAS} \text { significant drop in } \\
\mathrm{SaO}_{2} \text { in both groups }\end{array}$ & P 0.05 \\
\hline $\begin{array}{l}\text { Gunderson et al, } \\
1986(33)\end{array}$ & $\begin{array}{l}\text { Prematures with RDS, } \\
\text { intubated, ventilated } \\
(n=11)\end{array}$ & $\begin{array}{l}\text { Adaptor } \\
\text { RC } \\
\text { 1. PVETS } \\
\text { 2. NVETS }\end{array}$ & $\begin{array}{c}\text { Change in } \mathrm{TcPO}_{2}: \\
2.9 \% \text { in PVETS } \\
21.4 \% \text { in NVETS }\end{array}$ & $P=0.001$ & $\begin{array}{l}\text { Change in HR } \\
3.4 \% \text { in PVETS } \\
11.3 \% \text { in NVETS }\end{array}$ & $P=0.047$ \\
\hline $\begin{array}{l}\text { Bodai et al, } \\
1989(34)\end{array}$ & $\begin{array}{l}\text { Respiratory failure, } \\
\text { intubated, ventilated } \\
(n=15)\end{array}$ & $\begin{array}{l}\text { Adaptor } \\
\text { RC } \\
\text { 1. Suction } \\
\text { 2. Suction with NeoSafe valve }\end{array}$ & $\begin{array}{l}\mathrm{SaO}_{2} \text { desaturation with } \\
\text { NeoSafe } 9.8 \% \text {, with } \\
\text { conventional suction } 22 \%\end{array}$ & P 0.05 & & \\
\hline $\begin{array}{l}\text { Zmora and } \\
\text { Merritt, } 1980 \\
\text { (35) }\end{array}$ & $\begin{array}{l}\text { Newborns, RDS, } \\
\text { pneumonia, } \\
\text { asphyxia, } \\
\text { Gl surgery, } \\
\text { intubated, ventilated } \\
(\mathrm{n}=13)\end{array}$ & $\begin{array}{l}\text { Adaptor } \\
\text { Cohort } \\
\text { 1. ETT adapter with side holes } \\
\text { 2. ETT adapter with end hole }\end{array}$ & $\begin{array}{l}\mathrm{TcPO}_{2} \text { decreased less with } \\
\text { side-hole adapter }\end{array}$ & P 0.01 & $\begin{array}{l}\text { Occurrence of bradycardia } \\
\text { less in six, no different in } \\
11 \text { and considerably } \\
\text { worse in } 1\end{array}$ & P 0.01 \\
\hline $\begin{array}{l}\text { Kerem et al, } \\
1990 \text { (37) }\end{array}$ & $\begin{array}{l}\text { Infants in the ICU, } \\
\text { intubated and } \\
\text { ventilated, one day } \\
\text { to } 10 \text { years }(n=25)\end{array}$ & $\begin{array}{l}\text { Hyperinflation/Hyperoxygena- } \\
\text { tion } \\
\mathrm{RC} \\
\text { 1. Suction } \\
\text { 2. Preoxygenation by } \\
\text { ventilator } \\
\text { 3. Hyperinflation presuction } \\
\text { 4. Hyperinflation postsuction }\end{array}$ & Drop in $\mathrm{PaO}_{2}$ of $24 \mathrm{mmHg}$ in 1 & P 0.001 & Drop in $\mathrm{SaO}_{2}$ of $4.4 \%$ in 1 & P 0.001 \\
\hline $\begin{array}{l}\text { Feaster et al, } \\
1985 \text { (38) }\end{array}$ & $\begin{array}{l}\text { Children requiring } \\
\text { chronic respiratory } \\
\text { support, eight } \\
\text { months to three } \\
\text { years, (BPD and } \\
\text { myopathy) }(n=7)\end{array}$ & $\begin{array}{l}\text { Hyperinflation/Hyperoxygena- } \\
\text { tion } \\
\text { RC } \\
\text { 1. Hyperinflation alone } \\
\text { 2. Hyperinflation + } \\
\text { hyperoxygenation } \\
\text { 3. Hyperinflation + } \\
\text { hyperventilation } \\
\text { 4. Hyperinflation + } \\
\text { hyperoxygenation + } \\
\text { hyperventilation }\end{array}$ & $\begin{array}{l}\text { Change in } \mathrm{SpO}_{2} \text { presuction to } \\
30 \mathrm{~s} \text { after suction } \\
\text { Only statistically significant } \\
\text { difference was for } 4 \text {, but all } \\
\text { methods prevented significant } \\
\text { desaturation } \\
\mathrm{SaO}_{2} \text { did not drop below } 90 \%\end{array}$ & $\begin{array}{c}\text { NS } \\
\text { (clinically) }\end{array}$ & & \\
\hline
\end{tabular}

BP Blood pressure; BPD Bronchopulmonary dysplasia; CPT Chest physical therapy; ETT Endotracheal tube; $\mathrm{FiO}_{2}$ Fractional inspired concentration of oxygen; GI Gastrointestinal; HR Heart rate; ICP Intracranial pressure; ICU Intensive care unit; IV Intravenous; MAS Meconium aspiration syndrome; NS Not significant; NVETS Nonventilated endotracheal suction; OP Oropharyngeal suctioning; $\mathrm{PaO}_{2}$ Arterial pressure of oxygen; PVETS Partially ventilated endotracheal suction with adapter; q6h Every 6 h; q12h Every 12 h; RC Randomized crossover; RCT Randomized, controlled trial; RDS Respiratory distress syndrome; SaO 2 Arterial oxygen saturation; $\mathrm{SpO}_{2}$ Oxygen saturation by pulse oximetry; Stats Statistics; $T c P \mathrm{O}_{2}$ Transcutaneous partial pressure of oxygen 
Nonintubated neonates with evidence of MAS: Meconium is the bowel content of a fetus, usually passed within $48 \mathrm{~h}$ of delivery. If meconium is passed in utero, it is possible for the fetus to aspirate the meconium before or during delivery $(16,17)$. This aspirated meconium may cause airway obstruction and air trapping, and may support bacterial growth. The usual practice is to monitor amniotic fluid for the presence of meconium, and to suction the infant at the perineum during delivery $(16,17)$.

Three types of catheters and suctioning systems have been used to suction the upper airway of neonates at birth. With the bulb catheter, the suctioning pressure is provided by intermittent manual compression of the bulb. With the DeLee catheter, the operator provides the suctioning pressure by generating a negative pressure orally. This catheter places operators at risk of suctioning the infant's airway contents into their mouth. A third system - wall suction - provides suctioning pressure by a central vacuum system.

After the infant with evidence of meconium-stained amniotic fluid has been delivered, the two approaches to clinical care are suctioning of the infant's oropharynx, and suctioning of the infant's trachea using direct visualization and a meconium adaptor to apply suction directly to the endotracheal tube (ETT) $(18,19)$.

There were two studies (one RCT [16], one comparative cohort study [17]) comparing DeLee with bulb suctioning in neonates with evidence of MAS. In these two studies, there was no difference between DeLee and bulb suctioning for frequency of MAS and death, or the amount of meconium recovered; however, both studies lacked the statistical power to detect such a difference. No studies used wall suctioning in this patient population.

Two studies compared oropharyngeal suctioning with tracheal suctioning in neonates with evidence of MAS; one was an RCT (18) and the other a comparative cohort study (19). Neither study provided evidence of a benefit for tracheal suctioning over oropharyngeal suctioning alone. In the comparative cohort study (19), which was subject to allocation bias, some harmful effects of tracheal suctioning were noted - ie, the presence of stridor.

Recommendations: The DeLee and bulb methods are equally effective in the aspiration of meconium when suctioning nonintubated neonates with evidence of MAS. Because there is a risk to the operator associated with DeLee suction, it is not recommended. In vaginally delivered infants with MAS, no evidence exists to suggest a difference in the effectiveness of oropharyngeal compared with tracheal suctioning.

Nonintubated neonates without evidence of MAS: One published comparative cohort study was found on the indication for oropharyngeal suctioning in full-term, vaginally delivered infants without evidence of MAS (20). The study described the effect of oropharyngeal suctioning at birth on the mechanical properties of the respiratory system. There were no differences between the groups with respect to any of the outcomes (dynamic compliance on inspiration and expiration, and total resistance of the respiratory system). Given the paucity of literature, we are unable to make recommendations regarding suctioning of vaginally delivered infants (who have no evidence of MAS immediately after birth.

Intubated neonates, preterm and full-term - effect of hyperoxygenation, preoxygenation and hyperventilation: Hyperoxygenation is defined as the administration of oxygen at an inspired fractional concentration $\left(\mathrm{FiO}_{2}\right)$ that is greater than that which the individual is receiving or usually requires before, during or after suctioning. In an effort to reduce hypoxemia during suctioning, increased levels of oxygenation may be delivered before, during and/or after suctioning. Preoxygenation refers to hyperoxygenation before initiation of suctioning. Hyperventilation is an increase in ventilation but does not imply an increase in oxygen concentration.

The effects of different degrees of hyperventilation and preoxygenation in preterm neonates were examined in two studies - one randomized (21) and one nonrandomized crossover study (22) - neither of which used a control group of no preoxygenation and hyperventilation. Due to differences in outcomes and interventions, and problems with the analysis of the data, we are unable to make a recommendation on the timing of hyperventilation and hyperoxygenation (ie, before, during or after suctioning), or on different combinations of hyperoxygenation and hyperventilation in this patient population.

Three studies examined the effectiveness of preoxygenation alone: one randomized (23) and two nonrandomized crossover studies $(24,25)$. One study (25) included some full-term infants. All three studies showed an improvement in oxygenation with preoxygenation; however, none of these studies addressed the potentially negative effects of hyperoxia in preterm infants (eg, retinopathy of prematurity).

Recommendation: Individualized preoxygenation should be applied in intubated and ventilated preterm and fullterm infants to improve oxygenation.

Intubated neonates, preterm and full-term - frequency of suctioning: One study (RCT) examined the effect of suctioning frequency (either every $6 \mathrm{~h}$ or every $12 \mathrm{~h}$ ) (26). Although the study reported a relative reduction in death of $7 \%$ in those suctioned every $6 \mathrm{~h}$, the difference was not statistically significant and might have resulted from differences in other confounding variables. The high variability in death rate in the preterm population precludes a recommendation based solely on this study.

Intubated neonates, preterm and full-term - drugs for muscle paralysis: The relation between cerebral perfusion and hypoxic-ischemic lesions such as periventricular leukomalacia and intraventricular hemorrhage is not well understood. Some researchers have speculated that maintaining a consistent cerebral perfusion pressure (CPP) may reduce the potential for hypoxic-ischemic lesions (27). One nonrandomized crossover study (27) examined the effect of muscle paralysis 
using pancuronium intravenous bromide on variations in CPP in preterm infants. This study showed that muscle paralysis in ventilated preterm infants minimizes increases in intracranial pressure (ICP) during suctioning; however, the long term benefit of a transient minimization in ICP is unknown. Before the use of muscle paralyzing drugs can be recommended, further study of this intervention is warranted.

Intubated neonates, preterm and full term - drugs for pain relief during suctioning: Term and preterm infants experience pain during suctioning, and local and systemic analgesics are widely used. Because crying is not easily assessed in intubated infants, physiological parameters (vital signs, arterial oxygen saturation $\left[\mathrm{SaO}_{2}\right]$, stress hormones, cerebral blood flow) are used as indicators of pain.

Three studies - one randomized crossover (28), one RCT (29) and one nonrandomized crossover trial (30)-examined pain relief during suctioning using a variety of drugs (alfentanil, meperidine, phenobarbital). Although these studies do not provide clear evidence of benefit or harm of analgesic use, clinicians should consider the need for pain relief for infants on an individual basis.

Intubated neonates, preterm and full term - instillation: Instillation refers to the instillation of aliquots of saline directly into the ETT or tracheostomy tube to facilitate secretion removal. Two randomized crossover studies examined the effect of instillation $(31,32)$. Neither study made comparisons between groups; they only reported differences over time. No recommendation is offered on instillation of saline in ventilated preterm and full-term infants.

Intubated neonates, preterm and full term - adaptor: Adaptors with capped apertures have been a part of the patient ventilator circuit for many years. When opened, the aperture permits suctioning of intubated, ventilated patients without disconnection from the ventilator circuit. A meconium adaptor is used to connect the ETT to the suction tubing, and a porthole on the adaptor allows control over the application of suction.

Two randomized crossover $(33,34)$ and two nonrandomized crossover $(35,36)$ trials examined the effects of adaptors designed to maintain pressure and/or ventilation during suctioning. Two studies $(33,34)$ used a modified Wye adaptor with an end hole for suctioning, while the other two $(35,36)$ used a modified ETT adaptor that allows suctioning through a side hole. All studies showed a beneficial effect for the use of an adaptor on oxygenation.

Recommendation: Adaptors should be used in mechanically ventilated preterm and full-term infants with respiratory distress syndrome for whom hypoxemia is a concern.

Intubated infants and children - hyperventilation and hyperoxygenation: There were two randomized crossover studies on the effect of hyperventilation and hyperoxygenation in infants and children during suctioning $(37,38)$. One of the studies (37) examined intubated children, aged one day to 10 years (noncyanotic heart disease, central nervous system diseases, respiratory failure and sepsis), while the other (38) examined children aged eight months to three years requiring chronic respiratory support. These studies compared several protocols using combinations of hyperventilation and hyperoxygenation. Neither study performed comparisons between groups; however, in pre-post suction analysis, the studies indicated that no oxygen desaturation occurred with suctioning with hyperoxygenation and hyperventilation, or a combination of these techniques. There is insufficient evidence to make recommendations concerning hyperventilation and hyperoxygenation in infants and children.

Summaries and recommendations in adults: In the adult population, we examined the evidence related to the following techniques and tools for suctioning: preoxygenation, hyperoxygenation, hyperinflation, insufflation, methods of delivery, use of adaptors, open versus closed systems, catheter designs and types, instillation and use of medication. Where study populations differed significantly, evidence was summarized based on patient population. Tables 3 and 4 contain information about the studies that was used to formulate the following recommendations.

Preoxygenation: In addition to evacuating secretions, endotracheal suctioning removes oxygen-containing air from the tracheobronchial tree. Consequently, a decrease in the arterial pressure of oxygen $\left(\mathrm{PaO}_{2}\right)$ is associated with suctioning. Various methods of preoxygenating patients, particularly those who are intubated, have been used to ameliorate this reduction.

Two randomized crossover $(39,40)$ and two comparative cohort $(41,42)$ studies on preoxygenation were retrieved. Both of the randomized crossover studies involved patients with respiratory failure. One of the comparative cohort studies examined the effects of preoxygenation in postoperative cardiac surgery (42), while the other focused on patients undergoing lung resections (41). Two of the studies used ventilators to deliver the preoxygenation $(39,40)$, one used a manual resuscitation bag $(\mathrm{MRB})$ with $15 \mathrm{~L} / \mathrm{min}$ oxygen flow (42), and another study used either an MRB or a ventilator (41). All four studies showed a beneficial effect of preoxygenation on $\mathrm{PaO}_{2}$ or $\mathrm{SaO}_{2}$.

Recommendation: Mechanically ventilated adult patients should receive additional oxygenation before suctioning.

Hyperoxygenation and hyperinflation: Five randomized crossover trials examined the combination of hyperoxygenation and hyperinflation (43-47). Because the outcomes of interest were different, recommendations for medical/surgical patients were separated from those for head-injured patients. Hyperoxygenation and hyperinflations were delivered by either MRB or ventilator. Studies varied in the attention paid to the volumes and amount of oxygen actually being delivered to the patient. Only some studies accounted for ventilator washout time.

There were four studies in mechanically ventilated medical and surgical patients, which showed that hyperoxygenation helps in maintaining oxygen levels (43-46); however, the added value of hyperinflation was unclear. In one study involving patients with chronic obstructive pulmonary dis- 
TABLE 3

Summary of studies in adults related to preoxygenation, hyperoxygenation, hyperinflation, oxygen insufflation and the use of adaptors

\begin{tabular}{|c|c|c|c|c|c|c|}
\hline $\begin{array}{l}\text { Author, } \\
\text { year } \\
\text { (reference) }\end{array}$ & Population & Treatment allocation & Primary study outcome & $\mathbf{P}$ & $\begin{array}{l}\text { Secondary } \\
\text { outcome } \\
\text { (could also be } \\
\text { primary) }\end{array}$ & $\mathbf{P}$ \\
\hline $\begin{array}{l}\text { Craig et al, } \\
1984(39)\end{array}$ & $\begin{array}{l}\text { Intubated, ventilated } \\
\text { for acute } \\
\text { respiratory failure } \\
(n=17)\end{array}$ & $\begin{array}{l}\text { Preoxygenation } \\
\text { RC } \\
\text { 1. Preoxygenated, } 3 \text { min } 100 \% \mathrm{O}_{2} \\
\text { 2. No preoxygenation }\end{array}$ & $\begin{array}{l}\text { Decrease in } \mathrm{SaO} \text { greater } \\
\text { with no preoxygenation }\end{array}$ & $\begin{array}{c}\mathrm{P}<0.04 \\
\text { (clinically } \\
\mathrm{NS} \text { ) }\end{array}$ & & \\
\hline $\begin{array}{l}\text { Brown et al, } \\
1983(40)\end{array}$ & $\begin{array}{l}\text { Respiratory failure, } \\
\text { ventilated, copious } \\
\text { secretions (COPD) } \\
\text { (phase } 1, n=12 \\
\text { phase } 2, n=10 \\
\text { phase } 3, n=9 \text { ) }\end{array}$ & $\begin{array}{l}\text { Preoxygenation/use of adaptor } \\
\text { RC } \\
\text { Phase } 1 \\
\text { 1. Suction without extra breaths } \\
\text { 2. Suction after four breaths } \\
\text { 3. Suction with four postsuction breaths } \\
\text { 4. Suction through adaptor } \\
\text { Phase } 2 \\
\text { 1. Suction on ventilator using adaptor } \\
\text { 2. Suction off ventilator with six presuctioning } \\
\text { breaths at } \mathrm{FiO}_{2} \text { of } 1 \\
\text { 3. Suction off ventilator with six postsuctioning } \\
\text { breaths at } F \mathrm{Fi}_{2} \text { of } 1 \\
\text { 4. Suction off ventilator with six pre- and six } \\
\text { postsuctioning breaths at } F \mathrm{~F}_{2} \text { of } 1 \\
\text { Phase } 3 \\
\text { 1. Four successive passes off ventilator with six } \\
\text { presuction breaths at } F \mathrm{Fi}_{2} \text { of one after each pass } \\
\text { 2. Four passes on adaptor }\end{array}$ & $\begin{array}{l}\text { Phase } 1 \\
\text { No difference in decline in } \\
\mathrm{SaO}_{2} \text { among groups } 1,2 \\
\text { and } 3 \text {; decline in group } 4 \\
\text { was less } \\
\text { Phase } 2 \\
\text { No difference in decline in } \\
\mathrm{SaO}_{2} \text { among groups } 1,2 \\
\text { and } 4 \text {; decline in group } 3 \\
\text { was greater } \\
\text { Phase } 3 \\
\text { No difference in mean } \\
\text { saturation between groups } \\
1 \text { and } 2\end{array}$ & $P<0.05$ & $\begin{array}{l}\text { Mean desatura- } \\
\text { tion time was } \\
\text { shortened by ei- } \\
\text { ther four post- } \\
\text { breaths or using } \\
\text { adaptor } \\
\text { No differences in } \\
\text { desaturation } \\
\text { time or recovery }\end{array}$ & $P<0.05$ \\
\hline $\begin{array}{l}\text { Downes et al, } \\
1961 \text { (41) }\end{array}$ & $\begin{array}{l}\text { Adolescents and } \\
\text { adults, } \\
\text { intraoperative lung } \\
\text { resections, } \\
\text { anesthetized } \\
(\mathrm{n}=10, \text { intact } \\
\text { pleurae) }\end{array}$ & $\begin{array}{l}\text { Preoxygenation } \\
\text { Cohort } \\
\text { Series } 1 \\
\text { No prior hyperventilation } \\
\text { 1. } 1 \text { min of apnea } \\
\text { 2. } 1 \text { min of apnea + suction }(20 \mathrm{~s} \text { through } \\
\text { side connector) } \\
\text { Series } 2 \\
15 \text { s of hyperventilation with } \mathrm{O}_{2} \\
\text { 1. } 1 \text { min of apnea } \\
\text { 2. } 1 \text { min of apnea + suction } \\
\text { 3. } 2 \text { min of apnea }\end{array}$ & $\begin{array}{l}\text { Mean changes in } \mathrm{SaO}_{2} \\
\text { between hyperventilated } \\
\text { and nonhyperventilated } \\
\text { were all different } \\
\text { Mean change in } \mathrm{SaO}_{2} \text { not } \\
\text { significantly different } \\
\text { between } 1 \text { and } 2\end{array}$ & $P<0.01$ & & \\
\hline $\begin{array}{l}\text { Belknap et al, } \\
1980(42)\end{array}$ & $\begin{array}{l}\text { Postop CABG, } \\
\text { ventilated }(n=13)\end{array}$ & $\begin{array}{l}\text { Preoxygenation or bag versus ventilator } \\
\text { Cohort } \\
\text { 1. Presuctioning hyperinflation } \\
\text { 2. Hyperoxygenation }\left(100 \% \mathrm{O}_{2}\right)\end{array}$ & $\begin{array}{l}\text { Mean } \mathrm{PaO}_{2}: 157 \mathrm{mmHg} \\
\text { when hyperinflated with } \\
\text { ventilator; } 188 \mathrm{mmHg} \\
\text { when hyperoxygenated } \\
\text { with bag }\end{array}$ & $P<0.05$ & $\begin{array}{l}\text { No differences } \\
\text { found in } \mathrm{PCO}_{2}\end{array}$ & NS \\
\hline $\begin{array}{l}\text { Lookinland } \\
\text { and Appel, } \\
1991 \text { (43) }\end{array}$ & $\begin{array}{l}\text { Non head-injured } \\
\text { trauma patients, } \\
\text { no underlying lung } \\
\text { disease }(n=24)\end{array}$ & $\begin{array}{l}\text { Hyperoxygenation and hyperinflation } \\
\mathrm{RC} \\
\text { 1. Control: six breaths before and after } \\
\text { suctioning } \\
\text { 2. Hyperoxygenation alone: three breaths } \\
\text { maintenance } \mathrm{TV}, \mathrm{FiO}_{2} \text { of } 1.0 \\
\text { 3. Hyperinflation alone: three breaths at } 150 \% \\
\text { of } \mathrm{TV} \text { and same } \mathrm{FO}_{2} \\
\text { 4. Hyperinflation and hyperoxygenation: three } \\
\text { breaths at } 150 \% \mathrm{TV}, \mathrm{FiO}_{2} \text { of } 1\end{array}$ & $\begin{array}{l}\text { Mean arterial pressure, } \\
\text { pulmonary artery pressure, } \\
\text { mean capillary wedge } \\
\text { pressure and cardiac } \\
\text { output: no differences } \\
\text { among the four groups }\end{array}$ & NS & $\begin{array}{l}\text { Mean } \mathrm{PaO}_{2} \text { in } 2 \\
\text { and } 4 \text { greater } \\
\text { than in } 1 \text { and } 3 \\
\text { at end of } \\
\text { suctioning }\end{array}$ & $P<0.01$ \\
\hline $\begin{array}{c}\text { Rogge et al, } \\
1989 \text { (44) }\end{array}$ & $\begin{array}{l}\text { Patients with } x \text {-ray } \\
\text { evidence of COPD, } \\
\text { ventilated }(n=11)\end{array}$ & $\begin{array}{l}\text { Hyperoxygenation and hyperinflation } \\
\mathrm{RC} \\
\text { 1. Hyperoxygenation with } \mathrm{FiO}_{2} \text { of } 1 \\
\text { 2. Hyperoxygenation with maintenance } \mathrm{FiO}_{2}+ \\
20 \%\end{array}$ & $\begin{array}{l}\mathrm{BP}, \mathrm{SpO}_{2}, \mathrm{HR} \text {, cardiac } \\
\text { rhythm: no difference in } \\
\text { any variable during either } \\
\text { protocol }\end{array}$ & NS & & \\
\hline $\begin{array}{l}\text { Skelley et al, } \\
1980(45)\end{array}$ & $\begin{array}{l}\text { Postoperative } \\
\text { cardiac surgery, } \\
\text { ventilated }(n=11)\end{array}$ & $\begin{array}{l}\text { Hyperoxygenation and hyperinflation } \\
\text { RC } \\
\text { 1. Suctioning without preoxygenation } \\
\text { 2. One hyperinflation breath with } 100 \% \text { oxygen } \\
\text { 3. Three hyperinflation breaths with } 100 \% \\
\text { oxygen }\end{array}$ & $\begin{array}{l}\text { Immediately after and at } \\
90 \mathrm{~s} \text { and } 180 \mathrm{~s} \text {, significant } \\
\text { difference in } \mathrm{PaO}_{2} \\
\text { between } 1 \text { and } 3 \text {, and } \\
\text { between } 2 \text { and } 3\end{array}$ & $\begin{array}{l}P<0.01 \text {, but } \\
\text { clinically } N S\end{array}$ & & \\
\hline $\begin{array}{l}\text { Langrehr et al, } \\
1981(46)\end{array}$ & $\begin{array}{l}\text { Postoperative } \\
\text { cardiac surgery, } \\
\text { ventilated }(n=10)\end{array}$ & $\begin{array}{l}\text { Hyperoxygenation and hyperinflation/ } \\
\text { insufflation } \\
\text { RC } \\
\text { 1. One hyperinflation, hyperoxygenation }(100 \% \\
\text { oxygen) } \\
\text { 2. Three hyperinflations, hyperoxygenation } \\
\text { (100\% oxygen) } \\
\text { 3. Oxygen insufflation by catheter }(10 \mathrm{~L} / \mathrm{min}) \\
\text { 4. Oxygen insufflation by catheter }(15 \mathrm{~L} / \mathrm{min})\end{array}$ & $\begin{array}{l}\text { No difference in } \mathrm{PaO}_{2} \\
\text { between } 3 \text { and } 4 \text { at any } \\
\text { point } \\
\text { Immediately after suctioning, } \\
\text { significant differences } \\
\text { between } 2 \text { and } 3,2 \text { and } 4 \text {, } \\
\text { and } 1 \text { and } 2\end{array}$ & $P<0.05$ & & \\
\hline
\end{tabular}


TABLE 3 (continued)

Summary of studies in adults related to preoxygenation, hyperoxygenation, hyperinflation, oxygen insufflation and the use of adaptors

\begin{tabular}{|c|c|c|c|c|c|c|}
\hline $\begin{array}{l}\text { Author, } \\
\text { year } \\
\text { (reference) }\end{array}$ & Population & Treatment allocation & Primary study outcome & $\mathbf{P}$ & $\begin{array}{c}\text { Secondary } \\
\text { outcome } \\
\text { (could also be } \\
\text { primary) }\end{array}$ & $\mathbf{P}$ \\
\hline $\begin{array}{l}\text { Rudy et al, } \\
1991 \text { (47) }\end{array}$ & $\begin{array}{l}\text { Severe head injury, } \\
\text { intubated and } \\
\text { ventilated }(n=30)\end{array}$ & $\begin{array}{l}\text { Hyperoxygenation and hyperinflation } \\
\text { RC } \\
\text { 1. Two ET suctioning sequences, hyperoxygena- } \\
\text { tion and hyperoxygenation with hyperinflation } \\
(135 \% \text { TV) } \\
\text { 2. Three ET suctioning sequences, } \\
\text { hyperoxygenation (four breaths of } 100 \% \mathrm{O}_{2} \text { ) } \\
\text { and one with hyperoxygenation and } \\
\text { hyperinflation }(135 \% \mathrm{TV})\end{array}$ & $\begin{array}{l}\text { Mean ICP } \\
\text { No difference with addition } \\
\text { of hyperinflation in group } 1 \\
\text { Significant differences } \\
\text { across time } \\
\text { No significant difference } \\
\text { between } 2 \text { and } 3 \text { suction } \\
\text { sequences }\end{array}$ & $\begin{array}{c}\text { NS } \\
P<0.001 \\
\text { NS }\end{array}$ & $\begin{array}{l}\text { MAP, HR and } \\
\text { CPP all } \\
\text { behaved } \\
\text { similarly to } \\
\text { mean ICP }\end{array}$ & \\
\hline $\begin{array}{l}\text { Kelly et al, } \\
1987 \text { (48) }\end{array}$ & $\begin{array}{l}\text { Before cardiac } \\
\text { surgery, fully } \\
\text { anesthetized } \\
(n=38)\end{array}$ & $\begin{array}{l}\text { Oxygen insufflation } \\
\mathrm{RC} \\
\text { 1. } 20 \mathrm{~s} \text { suctioning with } \mathrm{O}_{2} \text { using a double } \\
\text { lumen catheter } \\
\text { 2. } 20 \mathrm{~s} \text { of continuous suctioning without } \mathrm{O}_{2} \\
\text { insufflation }\end{array}$ & $\begin{array}{l}\text { With insufflation, } \mathrm{PaO}_{2} \\
\text { increased by } 5 \text { torr } \\
\text { Without insufflation, } \mathrm{PaO}_{2} \\
\text { dropped } 16 \text { torr }\end{array}$ & $P<0.01$ & & \\
\hline $\begin{array}{l}\text { Dam et al, } \\
1994(49)\end{array}$ & $\begin{array}{l}\text { Postoperative CABG } \\
\text { surgery, ventilated } \\
(n=20)\end{array}$ & $\begin{array}{l}\text { Oxygen insufflation } \\
\text { RC } \\
\text { 1. Suction with a double lumen insufflation } \\
\text { catheter } 100 \% \mathrm{O}_{2} \\
\text { 2. Suction with a single lumen catheter, } \\
\text { ventilator } 100 \% \mathrm{O}_{2}\end{array}$ & $\begin{array}{l}\text { Arterial pressure differences } \\
\text { favouring insufflation }\end{array}$ & $P<0.02$ & $\begin{array}{l}\mathrm{PaO}_{2} \\
\text { Significant } \\
\text { pre-post and } \\
\text { between group } \\
\text { differences }\end{array}$ & $P<0.001$ \\
\hline $\begin{array}{l}\text { Smith et al, } \\
1987(50)\end{array}$ & $\begin{array}{l}\text { Trauma, medical, or } \\
\text { neurosurgical } \\
\text { patients, ventilated } \\
(n=18)\end{array}$ & $\begin{array}{l}\text { Oxygen insufflation } \\
\mathrm{RC} \\
\text { 1. Double lumen (Jinotti) catheter, } 100 \% \mathrm{O}_{2} \text {, } \\
\text { and no preoxygenation } \\
\text { 2. Preoxygenation, } 3 \text { min ventilator at } 100 \% \mathrm{O}_{2} \text {, } \\
\text { then suction }\end{array}$ & $\begin{array}{l}\text { No difference in } \mathrm{SpO}_{2} \\
\text { between groups }\end{array}$ & NS & & \\
\hline $\begin{array}{l}\text { Taft et al, } \\
1991(51)\end{array}$ & $\begin{array}{l}\text { Patients in the ICU, } \\
\text { intubated and } \\
\text { ventilated }(n=23)\end{array}$ & $\begin{array}{l}\text { Oxygen insufflation } \\
\text { RC } \\
\text { 1. Conventional method: bag, five breaths } \\
100 \% \mathrm{O}_{2} \text { before and after suction two times } \\
\text { 2. Insufflation method: } 15 \mathrm{~s} \text { of } \mathrm{O}_{2} \text { at } 15 \mathrm{~L} / \mathrm{min} \\
\text { with single lumen catheter }\end{array}$ & $\begin{array}{l}\mathrm{PaO}_{2} \text { and } \mathrm{SaO}_{2} \text { : significant } \\
\text { interaction between } \\
\text { preoxygenation method } \\
\text { and time on mean } \mathrm{PaO}_{2} \\
\text { and } \mathrm{SaO}_{2} ; \text { statistics for } \\
\text { main effects of method not } \\
\text { reported }\end{array}$ & $P<0.001$ & $\begin{array}{l}\text { No significant } \\
\text { difference in HR } \\
\text { with either } \\
\text { method or time }\end{array}$ & NS \\
\hline $\begin{array}{l}\text { Stone et al, } \\
1989(52)\end{array}$ & $\begin{array}{l}\text { Postcardiac surgery, } \\
\text { intubated and } \\
\text { ventilated }(n=8)\end{array}$ & $\begin{array}{l}\text { Hyperinflation (degree) } \\
\text { RC } \\
\text { Hyperinflated at five different weight-based } \\
\text { inspiratory volumes (TV } 12,14,16,18 \mathrm{~mL} / \mathrm{kg} \text { ) }\end{array}$ & $\begin{array}{l}\text { Mean arterial pressure: no } \\
\text { differences between } \\
\text { groups; mean increase of } \\
15 \mathrm{mmHg} \text { over three } \\
\text { hyperinflation sequences } \\
\text { (not volume dependent) }\end{array}$ & $P<0.001$ & $\begin{array}{l}\text { No significant } \\
\text { difference in } \\
\mathrm{PaO}_{2} \text { with } \\
\text { different } \\
\text { volumes }\end{array}$ & NS \\
\hline $\begin{array}{l}\text { Stone, } 1990 \\
\quad(53)\end{array}$ & $\begin{array}{l}\text { Postcardiac surgery, } \\
\text { intubated and } \\
\text { ventilated }(n=26)\end{array}$ & $\begin{array}{l}\text { Hyperinflation (degree) } \\
\text { RC } \\
\text { Hyperinflated at five different weight-based } \\
\quad \text { inspiratory volumes (TV } 12,14,16,18 \mathrm{~mL} / \mathrm{kg} \text { ) }\end{array}$ & $\begin{array}{l}\text { No clinically significant } \\
\text { difference in } \mathrm{PaO}_{2} \text { with } \\
\text { volume }\end{array}$ & $\begin{array}{c}\mathrm{NS} \\
\text { (clinically) }\end{array}$ & $\begin{array}{l}\text { No differences in } \\
\text { HR based on } \\
\text { lung volume }\end{array}$ & NS \\
\hline $\begin{array}{l}\text { Preusser et al, } \\
1988(54)\end{array}$ & $\begin{array}{l}\text { Stable postop } \\
\text { cardiac surgery } \\
(n=10)\end{array}$ & $\begin{array}{l}\text { Bag versus ventilator } \\
\text { RC } \\
\text { Three lung inflation breaths, } 100 \% \mathrm{O}_{2} \text { by: } \\
\text { 1. A preprimed manual bag at two different } \\
\text { volumes } / \mathrm{kg} \\
\text { 2. A preprimed vent at two different volumes } / \mathrm{kg} \\
\text { (same as in 1) }\end{array}$ & $\begin{array}{l}\text { MAP showed no difference } \\
\text { between groups } 1 \text { and } 2\end{array}$ & NS & $\begin{array}{l}\text { No significant } \\
\text { difference in } \\
\mathrm{PaO}_{2} \text { between } \\
\text { groups } 1 \text { and } 2\end{array}$ & NS \\
\hline $\begin{array}{l}\text { Stone et al, } \\
1991 \\
(55,56)\end{array}$ & $\begin{array}{l}\text { Postcardiac surgery, } \\
\text { intubated and } \\
\text { ventilated }(n=34)\end{array}$ & $\begin{array}{l}\text { Hyperinflation (degree) } \\
\text { RC } \\
\text { Hyperinflated at five inspiratory volumes } \\
\quad(\text { TV } 12,14,16,18 \mathrm{~mL} / \mathrm{kg} \text { ) }\end{array}$ & $\begin{array}{l}\text { MAP increased with } \\
\text { sequences, not volume } \\
\text { dependent }\end{array}$ & NS & $\begin{array}{l}\text { Cardiac output } \\
\text { and PAP in- } \\
\text { creased with } \\
\text { sequences, not } \\
\text { volume depend- } \\
\text { ent }\end{array}$ & NS \\
\hline $\begin{array}{l}\text { Kerr et al, } \\
1997(57)\end{array}$ & $\begin{array}{l}\text { Severe head injured, } \\
\text { ventilated, } \\
\text { intubated } \\
\text { (phase } 1: n=29 \\
\text { phase } 2: n=3 \text { to } 37 \text { ) }\end{array}$ & $\begin{array}{l}\text { Hyperventilation } \\
\text { RC } \\
\text { Phase } 1 \\
\text { 1. Hyperventilation }(100 \%) \text {, four breaths } \\
\text { 2. Hyperventilation }(100 \%) \text {, eight breaths } \\
\text { Phase } 2 \\
\text { 1. Hyperventilation }(100 \%) \text {, four breaths } \\
\text { 2. Hyperventilation }(100 \%), 30 \text { breaths }\end{array}$ & $\begin{array}{l}\text { ICP and cerebral perfusion } \\
\text { pressure: no difference in } \\
\text { phase } 1 \text {; increasing rate } \\
\text { and number of breaths } \\
\text { resulted in significant } \\
\text { difference up to } 10 \text { min } \\
\text { after in phase } 2\end{array}$ & $P<0.001$ & & \\
\hline
\end{tabular}


TABLE 3 (continued)

Summary of studies in adults related to preoxygenation, hyperoxygenation, hyperinflation, oxygen insufflation and the use of adaptors

\begin{tabular}{|c|c|c|c|c|c|c|}
\hline $\begin{array}{l}\text { Author, } \\
\text { year } \\
\text { (reference) }\end{array}$ & Population & Treatment allocation & Primary study outcome & $\mathbf{P}$ & $\begin{array}{l}\text { Secondary } \\
\text { outcome } \\
\text { (could also be } \\
\text { primary) }\end{array}$ & $\mathbf{P}$ \\
\hline $\begin{array}{l}\text { Campbell, } \\
1991 \text { (58) }\end{array}$ & $\begin{array}{l}\text { Severe head injured } \\
\text { patients, ventilated } \\
(n=10)\end{array}$ & $\begin{array}{l}\text { Hyperinflation } \\
\text { RC } \\
\text { Hyperinflation at three different volumes } \\
\quad(\mathrm{TV} 14,16,18 \mathrm{~mL} / \mathrm{kg})\end{array}$ & $\begin{array}{l}\text { No effect of volume on mean } \\
\text { ICP } \\
\text { Mean ICP increased over } \\
\text { time and through the } \\
\text { hyperinflation and } \\
\text { suctioning sequences }\end{array}$ & NS & & \\
\hline $\begin{array}{l}\text { Grap et al, } \\
1996(59)\end{array}$ & $\begin{array}{l}\text { Medical, surgical, } \\
\text { trauma ICU } \\
\text { patients, moderate } \\
\text { or severe lung } \\
\text { injury, intubated, } \\
\text { ventilated }(\mathrm{n}=29)\end{array}$ & $\begin{array}{l}\text { Bag versus ventilator } \\
\text { RC } \\
\text { 1. Hyperoxygenation with bag using } 15 \mathrm{~L} / \mathrm{min} \\
\mathrm{O}_{2} \text { flow before and after suctioning } \\
\text { 2. Three mechanical breaths of } 100 \% \mathrm{O}_{2} \\
\text { before and after suctioning }\end{array}$ & $\begin{array}{l}\text { Significant difference in } \\
\mathrm{PaO}_{2} \text { between groups } \\
\text { Mean } \mathrm{PaO}_{2} \text { was higher } \\
\text { during ventilated breaths } \\
\text { immediately and } 30 \mathrm{~s} \\
\text { postsuctioning }\end{array}$ & $\begin{array}{l}P<0.01 \\
P<0.05\end{array}$ & $\begin{array}{l}\text { No significant } \\
\text { difference in } \\
\text { mean between } \\
\text { the groups }\end{array}$ & NS \\
\hline $\begin{array}{l}\text { Pierce and } \\
\text { Piazza, } \\
1987(60)\end{array}$ & $\begin{array}{l}\text { Cardiac surgery } \\
\text { patients }(n=30)\end{array}$ & $\begin{array}{l}\text { Bag versus ventilator } \\
\mathrm{RC} \\
\text { 1. Postoxygenation with bag at } 100 \% \mathrm{O}_{2} \\
\text { 2. Postoxygenation with three } 1000 \mathrm{~mL} \text { sighs } \\
\text { on ventilator with } 100 \% \mathrm{O}_{2}\end{array}$ & $\begin{array}{l}\mathrm{PaO}_{2} \text { increase greater in } \\
\text { group } 2\end{array}$ & $P=0.0007$ & $\begin{array}{l}\mathrm{SaO}_{2} \text { behaved } \\
\text { similarly but } \\
\text { may not be } \\
\text { clinically } \\
\text { meaningful }\end{array}$ & $P=0.013$ \\
\hline $\begin{array}{l}\text { Conforti, } 1982 \\
\quad(61)\end{array}$ & $\begin{array}{l}\text { Postop coronary } \\
\text { revascularization } \\
\text { and/or valve } \\
\text { replacement, } \\
\text { ventilated without } \\
\text { PEEP }(n=33)\end{array}$ & $\begin{array}{l}\text { Bag versus ventilator } \\
\mathrm{RC} \\
\text { 1. Hyperinflation by bag }\left(15 \mathrm{~L} / \mathrm{min} \mathrm{O}_{2}\right) \\
\text { 2. Hyperinflation by sigh on ventilator } \\
\left(100 \% \mathrm{O}_{2}\right)\end{array}$ & $\begin{array}{l}\mathrm{PaO}_{2} \text { rose after suctioning } \\
\text { compared with control for } \\
\text { both methods } \\
\mathrm{PaO}_{2} \text { increase greater with } \\
\text { ventilator }\end{array}$ & $P<0.001$ & $\begin{array}{l}\text { No differences in } \\
\mathrm{PaCO}_{2}\end{array}$ & NS \\
\hline $\begin{array}{l}\text { Anderson, } \\
1989(62)\end{array}$ & $\begin{array}{l}\text { Critically ill (mixed } \\
\text { medical/trauma), } \\
\text { intubated, } \\
\text { ventilated }(n=28)\end{array}$ & $\begin{array}{l}\text { Bag versus ventilator } \\
\text { Cohort } \\
\text { 1. Hyperinflation by bag } \\
\text { 2. Hyperinflation by ventilator sighs of } 1000 \mathrm{~mL} \\
\text { and } \mathrm{FO}_{2} 100 \%\end{array}$ & $\begin{array}{l}\text { Baseline to postsuctioning } \\
\text { change in } \mathrm{SpO}_{2} \text { signifi- } \\
\text { cantly greater with ventila- } \\
\text { tory sighing than with } \\
\text { bagging }\end{array}$ & $P=0.028$ & & \\
\hline $\begin{array}{l}\text { Belling et al, } \\
1978(63)\end{array}$ & $\begin{array}{l}\text { Postoperative } \\
\text { cardiac surgery, } \\
\text { ventilated }(n=20)\end{array}$ & $\begin{array}{l}\text { Use of adaptor } \\
\text { RC } \\
\text { 1. Swivel adapter and suction } \\
\text { 2. Disconnecting ventilator and suction }\end{array}$ & $\begin{array}{l}\text { Mean decrease in } \mathrm{PaO}_{2} \\
\text { through adaptor } 24.6 \% \\
\text { mean decrease off } \\
\text { ventilator } 67.4 \%\end{array}$ & $P<0.001$ & $\begin{array}{l}\text { Suctioning time } \\
\text { through adapter } \\
2.3 \text { min; off ven- } \\
\text { tilator time } \\
1.8 \text { min }\end{array}$ & $P=0.001$ \\
\hline $\begin{array}{l}\text { Jung and } \\
\text { Newman, } \\
1982(64)\end{array}$ & $\begin{array}{l}\text { Acute lung disease } \\
\text { in ICU, intubated } \\
(n=18)\end{array}$ & $\begin{array}{l}\text { Use of adaptor } \\
\text { RC } \\
\text { 1. Suctioned via standard ETT (disconnected } \\
\text { from ventilator) } \\
\text { 2. Suctioned through modified suction adaptor }\end{array}$ & $\begin{array}{l}\mathrm{SaO}_{2} \text { fell less during use of } \\
\text { adaptor }\end{array}$ & $P<0.01$ & $\begin{array}{l}\text { Difference in HR } \\
\text { response to the } \\
\text { two protocols, } \\
\text { NS }\end{array}$ & NS \\
\hline $\begin{array}{l}\text { Douglas and } \\
\text { Larson, } \\
1985(65)\end{array}$ & $\begin{array}{l}\text { Medical/surgical ICU } \\
\text { patients, no history } \\
\text { of chronic lung dis- } \\
\text { ease, ventilated } \\
(n=12)\end{array}$ & $\begin{array}{l}\text { PEEP valve } \\
\text { RC } \\
\text { 1. PEEP adaptor on the bag } \\
\text { 2. No adaptor on bag }\end{array}$ & $\begin{array}{l}\text { No significant effect of PEEP } \\
\text { on } \mathrm{PaO}_{2}\end{array}$ & NS & $\begin{array}{l}\text { No significant } \\
\text { difference in } \\
\text { mean } \mathrm{SaO}_{2}\end{array}$ & \\
\hline $\begin{array}{l}\text { Schumann } \\
\text { and } \\
\text { Parsons, } \\
1985(66)\end{array}$ & $\begin{array}{l}\text { ARDS patients, } \\
\quad \text { ventilated }(n=15)\end{array}$ & $\begin{array}{l}\text { PEEP valve } \\
\text { Cohort } \\
\text { 1. PEEP valve } \\
\text { 2. No PEEP valve }\end{array}$ & $\begin{array}{l}\mathrm{PaO}_{2} \text { increased from } 84 \text { to } \\
122 \text { mmHg with PEEP } \\
\text { valve and returned to } \\
\text { baseline by } 5 \text { min } \\
\text { Without } \mathrm{PEEP}, \mathrm{PaO}_{2} \text { in- } \\
\text { creased from } 92 \text { to } \\
106 \mathrm{mmHg} \text { and returned to } \\
\text { baseline by } 5 \text { min }\end{array}$ & $P<0.005$ & & \\
\hline
\end{tabular}

ARDS Acute respiratory distress syndrome; BP Blood pressure; bpm Beats/min; CABG Coronary artery bypass graft; COPD Chronic obstructive pulmonary disease; CPP Cerebral perfusion pressure; ET Endotracheal; ETT Endotracheal tube; $\mathrm{FiO}_{2}$ Fractional inspired concentration of oxygen; HR Heart rate; ICP Intracranial pressure; ICU Intensive care unit; MAP Mean arterial pressure; NS Not significant; $\mathrm{PaO}_{2}$ Arterial pressure of oxygen; PEEP Positive end expiratory pressure; Postop Postoperative; $R C$ Randomized crossover; $R C T$ Randomized controlled trial; $\mathrm{SaO}_{2}$ Arterial oxygen saturation; $\mathrm{SpO} \mathrm{O}_{2} \mathrm{Oxygen}$ saturation by pulse oximetry; $\mathrm{TCPO}_{2}$ Transcutaneous partial pressure of oxygen; TV Tidal volume

ease (44), lower levels of hyperoxygenation were safe and adequate; this suggests that hyperoxygenation should be individualized. For patients with severe head injury where ICP was a concern (47), there was no difference between hyperoxygenation alone and the combination of hyperoxygenation and hyperinflation on ICP, arterial blood pressure, heart rate or saturation.
Recommendations: For mechanically ventilated trauma, cardiac and chronic obstructive pulmonary disease patients, hyperoxygenation should be used during suctioning to maintain oxygen levels. For severely head-injured patients where ICP is a concern, hyperinflation before, during and/or after suctioning should not be added to hyperoxygenation ( $100 \%$ oxygen). 
TABLE 4

Summary of studies in adults related to open and closed systems, types and designs of catheters, instillation of saline, drugs and jet ventilation

\begin{tabular}{|c|c|c|c|c|c|c|}
\hline $\begin{array}{l}\text { Author, year } \\
\text { (reference) }\end{array}$ & Population & Treatment allocation & Primary outcome & $\mathbf{P}$ & $\begin{array}{l}\text { Secondary } \\
\text { outcome } \\
\text { (could also } \\
\text { be primary) }\end{array}$ & $\mathbf{P}$ \\
\hline $\begin{array}{c}\text { Deppe et al, } \\
1990(67)\end{array}$ & $\begin{array}{l}\text { Intubated, ventilated } \\
\quad(\mathrm{n}=84)\end{array}$ & $\begin{array}{l}\text { Open versus closed } \\
\text { RCT } \\
\text { 1. Open } \\
\text { 2. Closed }\end{array}$ & $\begin{array}{l}\text { Nosocomial pneumonia } \\
\text { Open: } 29 \% \\
\text { Closed: } 26 \%\end{array}$ & NS & $\begin{array}{l}\text { Colonization } \\
\text { Open: } 39 \% \\
\text { Closed: } 67 \%\end{array}$ & $\mathrm{P}<0.02$ \\
\hline $\begin{array}{c}\text { Adams et al, } \\
1997(68)\end{array}$ & $\begin{array}{l}\text { Postoperative liver } \\
\text { transplant, ventilated } \\
(n=20)\end{array}$ & $\begin{array}{l}\text { Open versus closed } \\
\text { RCT } \\
\text { 1. Open } \\
\text { 2. Closed }\end{array}$ & $\begin{array}{l}\text { Microbiological assessment of } \\
\text { secretions (colony count in } \\
\text { aspirates); no significant difference } \\
\text { at extubation }\end{array}$ & $P=0.05$ & $\begin{array}{l}\text { No cases of } \\
\text { pneumonia }\end{array}$ & \\
\hline $\begin{array}{l}\text { Conrad et al, } \\
1996(69)\end{array}$ & $\begin{array}{l}\text { Intubated, ventilated } \\
\qquad(\mathrm{n}=33)\end{array}$ & $\begin{array}{l}\text { Open versus closed } \\
\text { RCT } \\
\text { 1. Open } \\
\text { 2. Closed }\end{array}$ & $\begin{array}{l}\text { Frequency of nosocomial } \\
\text { pneumonia } \\
\text { Open: six of } 15(41 \%) \\
\text { Closed: six of } 16(38 \%)\end{array}$ & NS & $\begin{array}{l}\text { Frequency of } \\
\text { infection } \\
\text { Open: } 0.054 \\
\text { Closed: } 0.040\end{array}$ & NS \\
\hline $\begin{array}{l}\text { Ritz et al, } \\
1986(70)\end{array}$ & $\begin{array}{l}\text { Ventilated, with positive } \\
\text { sputum culture }\end{array}$ & $\begin{array}{l}\text { Open versus closed } \\
\text { Prospective crossover } \\
\text { 1. Open } \\
\text { 2. Closed }\end{array}$ & $\begin{array}{l}\text { No significant difference between } \\
\text { sputum culture from catheter tips } \\
\text { and sputum sample }\end{array}$ & NS & & \\
\hline $\begin{array}{l}\text { Cobley et al, } \\
1991 \text { (71) }\end{array}$ & $\begin{array}{l}\text { Ventilated, colonized } \\
\text { with Gram-negative } \\
\text { bacteria but without } \\
\text { significant infection } \\
(n=11)\end{array}$ & $\begin{array}{l}\text { Open versus closed } \\
\text { Prospective crossover } \\
\text { 1. Open } \\
\text { 2. Closed }\end{array}$ & $\begin{array}{l}\text { On average, } 18.6 \text { fewer colonies } \\
\text { with closed from the air sampled } \\
\text { Increased colony counts (settle) with } \\
\text { open system at } 50 \text { and } 100 \mathrm{~cm}\end{array}$ & $\begin{array}{l}P=0.001 \\
P<0.05\end{array}$ & & \\
\hline $\begin{array}{l}\text { Wu et al, } \\
1993(72)\end{array}$ & $\begin{array}{l}\text { Anesthetized patients } \\
\qquad(\mathrm{n}=8)\end{array}$ & $\begin{array}{l}\text { Open versus closed } \\
\text { Randomized crossover } \\
\text { 1. Open } \\
\text { 2. Closed }\end{array}$ & $\begin{array}{l}\text { Significantly greater drop in } \mathrm{PaO}_{2} \\
\text { with open system }\end{array}$ & $\begin{array}{l}\mathrm{P}<0.05 \\
\quad(\mathrm{NS} \\
\text { clinically) }\end{array}$ & & \\
\hline $\begin{array}{l}\text { Hardie and } \\
\text { Kirchhoff, } \\
1990(73)\end{array}$ & $\begin{array}{l}\text { Ventilated, respiratory } \\
\text { failure }(n=28)\end{array}$ & $\begin{array}{l}\text { Open versus closed } \\
\text { Randomized crossover } \\
\text { 1. Open } \\
\text { 2. Closed }\end{array}$ & $\begin{array}{l}\text { Stable } \mathrm{O}_{2} \text { saturation during and } \\
\text { following suction for both }\end{array}$ & NS & $\begin{array}{l}\text { No significant } \\
\text { difference in } \\
\text { HR }\end{array}$ & NS \\
\hline $\begin{array}{c}\text { Carlon et al, } \\
1987(74)\end{array}$ & $\begin{array}{l}\text { Intubated, ventilated } \\
\qquad(\mathrm{n}=20)\end{array}$ & $\begin{array}{l}\text { Open versus closed } \\
\text { Cohort } \\
\text { 1. Open } \\
\text { 2. Closed } \\
\text { Two cohorts based on PEEP }\end{array}$ & $\begin{array}{l}\text { No clinically important difference } \\
\text { detected in arterial blood gases }\end{array}$ & $\begin{array}{l}\text { NS } \\
\text { (clinically) }\end{array}$ & & \\
\hline $\begin{array}{l}\text { Johnson et al, } \\
1997(75)\end{array}$ & $\begin{array}{l}\text { Intubated, ventilated } \\
\text { ( } \mathrm{n}=35 ; 276 \\
\text { procedures })\end{array}$ & $\begin{array}{l}\text { Open versus closed } \\
\text { Prospective cohort } \\
\text { Quasirandomized } \\
\text { 1. Open } \\
\text { 2. Closed }\end{array}$ & $\begin{array}{l}\mathrm{O}_{2} \text { saturation } 30 \mathrm{~s} \text { postsuctioning } \\
0.4 \% \text { fall with open } \\
1.4 \% \text { increase with closed }\end{array}$ & $\begin{array}{l}\mathrm{P}<0.0001 \\
\mathrm{NS} \\
\text { (clinically) }\end{array}$ & $\begin{array}{l}\mathrm{PaO}_{2} 96 \text { with } \\
\text { open versus } \\
99 \text { with closed }\end{array}$ & $\begin{array}{l}\mathrm{P}<0.0001 \\
\mathrm{NS} \\
\text { clinically }\end{array}$ \\
\hline $\begin{array}{l}\text { Clark et al, } \\
1990(76)\end{array}$ & $\begin{array}{l}\text { Intubated but not all } \\
\text { ventilated }(n=189)\end{array}$ & $\begin{array}{l}\text { Open versus closed } \\
\text { Prospective cohort } \\
\text { 1. Open } \\
\text { 2. Closed }\end{array}$ & $\begin{array}{l}4 \% \text { fall in } \mathrm{SvO}_{2} \text { with open; } \\
\text { no change with closed }\end{array}$ & $P=0.0001$ & $\begin{array}{l}\text { No difference in } \\
\text { HR between } \\
\text { groups }\end{array}$ & NS \\
\hline $\begin{array}{l}\text { Witmer et al, } \\
1991 \text { (77) }\end{array}$ & $\begin{array}{l}\text { Ventilated patients in the } \\
\text { ICU }(n=25)\end{array}$ & $\begin{array}{l}\text { Open versus closed } \\
\text { Randomized crossover } \\
\text { 1. Open } \\
\text { 2. Closed }\end{array}$ & $\begin{array}{l}\text { No significant difference in mass of } \\
\text { sputum }\end{array}$ & $P=0.88$ & & \\
\hline $\begin{array}{l}\text { Harris and } \\
\text { Hyman, } \\
1984(78)\end{array}$ & $\begin{array}{l}\text { Newly tracheotomized } \\
\text { patients }(n=209)\end{array}$ & $\begin{array}{l}\text { Sterile versus clean } \\
\text { Retrospective chart review } \\
\text { 1. Sterile (five hospitals) } \\
\text { 2. Clean (five hospitals) }\end{array}$ & $\begin{array}{l}\text { Infection rate higher with sterile } \\
\text { procedure (versus clean and } \\
\text { mixed) based on tool developed } \\
\text { by investigators }\end{array}$ & Not stated & & \\
\hline $\begin{array}{l}\text { Freedman and } \\
\text { Goodman, } \\
1982(79)\end{array}$ & $\begin{array}{l}\text { Intubated, ventilated } \\
\qquad(\mathrm{n}=126)\end{array}$ & $\begin{array}{l}\text { Type of catheter } \\
\text { Cohort } \\
\text { 1. Straight } \\
\text { 2. Straight with traction of trachea to } \\
\text { right } \\
\text { 3. Straight with manipulation of } \\
\text { tracheostomy tube } \\
\text { 4. Coudé directed to left }\end{array}$ & $\begin{array}{l}\text { Significant difference in group } 4 \text {, } \\
\text { cannulation of left bronchi as } \\
\text { detected by chest x-ray }\end{array}$ & $P<0.05$ & & \\
\hline $\begin{array}{l}\text { Kirimli et al, } \\
1970(80)\end{array}$ & $\begin{array}{l}\text { Postoperative, intubated, } \\
\text { ventilated }(n=12)\end{array}$ & $\begin{array}{l}\text { Type of catheter } \\
\text { Prospective crossover } \\
\text { 1. Straight catheter } \\
\text { 2. Coudé catheter }\end{array}$ & $\begin{array}{l}\text { X-ray of catheter position } \\
\text { Straight: entered left } 3 / 35 \\
\text { regardless of procedure } \\
\text { Coudé: reached goal in } 50 \% \text { of } \\
\text { cases }\end{array}$ & Not stated & & \\
\hline
\end{tabular}


TABLE 4 (continued)

Summary of studies in adults related to open and closed systems, types and designs of catheters, instillation of saline, drugs and jet ventilation

\begin{tabular}{|c|c|c|c|c|c|c|}
\hline $\begin{array}{l}\text { Author, year } \\
\text { (reference) }\end{array}$ & Population & Treatment allocation & Primary outcome & $\mathbf{P}$ & $\begin{array}{l}\text { Secondary } \\
\text { outcome } \\
\text { (could also } \\
\text { be primary) }\end{array}$ & $\mathbf{P}$ \\
\hline $\begin{array}{c}\text { Kubota et al, } \\
1980(81)\end{array}$ & $\begin{array}{l}\text { Postanesthetic with } \\
\text { major surgery, } \\
\text { intubated }(n=104)\end{array}$ & $\begin{array}{l}\text { Type of catheter } \\
\text { Prospective crossover } \\
\text { 1. Portex straight and Coudé } \\
\text { 2. Rubber catheter straight and } \\
\text { Coudé }\end{array}$ & $\begin{array}{l}\text { X-ray of catheter position } \\
\text { Portex } \\
\text { Straight + neutral } 10 / 52(19 \%) \text {, } \\
\quad \text { rotation } 17 / 52(31 \%) \\
\text { Coudé + neutral } 21 / 52(40 \%), \\
\text { rotation } 13 / 52(25 \%) \\
\text { Rubber catheter } \\
\text { Straight + neutral } 8 / 52(15 \%) \text {, } \\
\text { rotation } 15 / 52(29 \%) \\
\text { Coudé + neutral } 26 / 52(50 \%), \\
\text { rotation } 12 / 52(23 \%)\end{array}$ & No statistics & & \\
\hline $\begin{array}{l}\text { Jung and } \\
\text { Gottlieb, } \\
1976(82)\end{array}$ & $\begin{array}{l}\text { Nonintubated with four } \\
\text { tracheotomized }(n=20)\end{array}$ & $\begin{array}{l}\text { Type of catheter } \\
\text { Prospective crossover } \\
\text { 1. Single eyelet } \\
\text { 2. Two eyelet } \\
\text { 3. Coudé } \\
\text { 4. "Beaded" }\end{array}$ & $\begin{array}{l}\text { Mucosal trauma with still and cine } \\
\text { photography } \\
\text { Negligible difference between } \\
\text { groups } 4 \text { and } 1 \\
\text { Gross traumatic effects - petechiae } \\
\text { Sucking effect more pronounced } \\
\text { with group } 2 \text { compared with } 4 \\
\text { Little mucosal trauma with either }\end{array}$ & No statistics & & \\
\hline $\begin{array}{r}\text { Valles et al, } \\
1995(83)\end{array}$ & Intubated $(\mathrm{n}=190)$ & $\begin{array}{l}\text { Catheter design } \\
\text { RCT } \\
\text { 1. Subglottic aspiration } \\
\text { 2. Control }\end{array}$ & $\begin{array}{l}\text { Decreased relative risk of } \\
\text { pneumonia - relative risk of } 1.76 \\
\text { compared with control }\end{array}$ & & $\begin{array}{l}\text { No difference in } \\
\text { hospital } \\
\text { mortality }\end{array}$ & NS \\
\hline $\begin{array}{l}\text { Mahul et al, } \\
1992(84)\end{array}$ & $\begin{array}{l}\text { Patients intubated for } \\
\text { more than three days } \\
(n=145)\end{array}$ & $\begin{array}{l}\text { Subglottic drainage (with special } \\
\text { ETT and use of a syringe) } \\
\text { RCT } \\
\text { 1. Control } \\
\text { 2. Subglottic drainage }\end{array}$ & $\begin{array}{l}\text { Nosocomial pneumonia } \\
\text { Control: } 29 \% \\
\text { Group } 2: 13 \%\end{array}$ & Not stated & $\begin{array}{l}\text { Time to onset of } \\
\text { pneumonia: } \\
\text { Control: } 8.3 \text { days } \\
\text { Group } 2: 16.2 \\
\text { days }\end{array}$ & $P<0.05$ \\
\hline $\begin{array}{l}\text { Schmidt et al, } \\
1995(85)\end{array}$ & $\begin{array}{l}\text { Intubated, ventilated } \\
\qquad(n=12 \text { for study } A \\
n=28 \text { for study } B)\end{array}$ & $\begin{array}{l}\text { Catheter type/saline } \\
\text { Randomized crossover } \\
\text { Study } A \\
\text { 1. Double lumen catheter, instills } \\
10 \mathrm{~mL} \text { saline } \\
\text { 2. Conventional catheter - no saline } \\
\text { instillation } \\
\text { Study B } \\
\text { 1. Double lumen catheter and } 10 \mathrm{~mL} \\
\text { saline - not discontinued from } \\
\text { ventilator } \\
\text { 2. Conventional catheter with } 10 \mathrm{~mL} \\
\text { instilled with ambu system }\end{array}$ & $\begin{array}{l}\text { Study } A \\
\mathrm{PaO}_{2}-\text { during } \\
\text { 1. } \mathrm{PaO}_{2}: 6.8 \mathrm{mmHg} \text { fall } \\
\text { 2. } \mathrm{PaO}_{2}: 21.1 \mathrm{mmHg} \text { fall } \\
\text { but increased after suction } \\
\mathrm{Study} B \\
\mathrm{PaO}_{2}-\text { immediately after } \\
\text { 1. } 1.0 \mathrm{mmHg} \text { fall } \\
\text { 2. } 25.9 \mathrm{mmHg} \text { fall }\end{array}$ & $\begin{array}{l}\text { No } \\
\text { value }\end{array}$ & $\begin{array}{l}\text { Secretion } \\
\quad \text { volume } \\
\text { Study } A \\
\text { 1. } 11.0 \mathrm{~mL} \\
\text { 2. } 0.84 \mathrm{~mL} \\
\text { Study } B \\
\text { 1. } 10.6 \mathrm{~mL} \\
\text { 2. } 2.5 \mathrm{~mL}\end{array}$ & $P<0.001$ \\
\hline $\begin{array}{l}\text { Isea et al, } \\
1993(86)\end{array}$ & $\begin{array}{l}\text { Ventilated patients who } \\
\text { required frequent } \\
\text { suctioning }(n=20)\end{array}$ & $\begin{array}{l}\text { Catheter type/saline } \\
\text { Randomized crossover } \\
\text { 1. Conventional catheter and } 10 \mathrm{~mL} \\
\text { of saline } 4 \\
\text { 2. Irrigated catheter with } 40 \mathrm{~mL} \text { of } \\
\text { saline }\end{array}$ & $\begin{array}{l}\text { Sputum volume (dry weight) } \\
\text { Irrigation catheter: } 1.04 \mathrm{~mL} \\
\text { Conventional: } 0.36 \mathrm{~mL}\end{array}$ & $P<0.005$ & $\begin{array}{l}\text { No difference in } \\
\mathrm{O}_{2} \text { saturation } \\
\text { between } \\
\text { groups }\end{array}$ & NS \\
\hline $\begin{array}{l}\text { Doorley et al, } \\
1990(87)\end{array}$ & Ventilated $(n=24)$ & $\begin{array}{l}\text { Type of catheter } \\
\text { Cohort } \\
\text { 1. Single lumen (Ballard) } \\
\text { 2. Double lumen (Concord } \\
\text { Steri-catheter) }\end{array}$ & $\begin{array}{l}\text { Effective secretion removal } \\
\text { (subjective report from suctioned) } \\
\text { - group } 1 \text { more effective }\end{array}$ & $P<0.05$ & $\begin{array}{l}\text { Fall in } \\
\mathrm{SpO}_{2}<85 \% \\
\text { (worse drop in } \\
\text { group 2) }\end{array}$ & $P<0.05$ \\
\hline $\begin{array}{l}\text { Bostick and } \\
\text { Wendelgass, } \\
1987 \text { (88) }\end{array}$ & $\begin{array}{l}\text { Postoperative open heart } \\
\text { surgery, ventilated } \\
(n=45)\end{array}$ & $\begin{array}{l}\text { Saline } \\
\text { RCT } \\
\text { 1. No saline } \\
\text { 2. } 5 \mathrm{~mL} \text { saline } \\
\text { 3. } 10 \mathrm{~mL} \text { saline }\end{array}$ & $\begin{array}{l}\text { No significant difference in } \mathrm{PaO}_{2} \\
\text { between groups when controlled } \\
\text { for pre- } \mathrm{O}_{2} \text { levels }\end{array}$ & NS & $\begin{array}{l}\text { No difference in } \\
\text { weight of } \\
\text { sputum } \\
\text { between } \\
\text { groups }\end{array}$ & NS \\
\hline $\begin{array}{l}\text { Gray et al, } \\
1990(89)\end{array}$ & $\begin{array}{l}\text { Critically ill, ventilated } \\
\qquad(n=15)\end{array}$ & $\begin{array}{l}\text { Saline } \\
\text { Randomized crossover } \\
\text { 1. } 5 \mathrm{~mL} \text { saline } \\
\text { 2. No saline }\end{array}$ & $\begin{array}{l}\text { No difference in gas exchange } \\
\text { between groups } \\
\text { Statistically different amount of } \\
\text { secretion removed }\end{array}$ & $\begin{array}{c}\text { NS } \\
P<0.05\end{array}$ & $\begin{array}{l}\text { No difference in } \\
\text { HR or BP } \\
\text { between } \\
\text { groups }\end{array}$ & NS \\
\hline $\begin{array}{l}\text { Ackerman } \\
\text { and Gugerty, } \\
1990(90)\end{array}$ & Ventilated $(n=26)$ & $\begin{array}{l}\text { Saline } \\
\text { Randomized crossover } \\
\text { 1. No saline } \\
\text { 2. } 5 \mathrm{~mL} \text { saline }\end{array}$ & Fall in $\mathrm{SaO}_{2}$ in group 2 & $\begin{array}{c}\mathrm{P}<0.05 \text { (not } \\
\text { clinically } \\
\text { important } \\
{[<2 \%] \text { ) }}\end{array}$ & $\begin{array}{l}\text { Significant } \\
\text { difference in } \\
\text { sputum weight } \\
\text { between } \\
\text { groups } \\
\text { (greater in } \\
\text { saline) }\end{array}$ & $P<0.05$ \\
\hline
\end{tabular}


TABLE 4 (continued)

Summary of studies in adults related to open and closed systems, types and designs of catheters, instillation of saline, drugs and jet ventilation

\begin{tabular}{|c|c|c|c|c|c|c|}
\hline $\begin{array}{l}\text { Author, year } \\
\text { (reference) }\end{array}$ & Population & Treatment allocation & Primary outcome & $\mathbf{P}$ & $\begin{array}{l}\text { Secondary } \\
\text { outcome } \\
\text { (could also } \\
\text { be primary) }\end{array}$ & $\mathbf{P}$ \\
\hline $\begin{array}{l}\text { Ackerman, } \\
1993(91)\end{array}$ & $\begin{array}{l}\text { Critically ill males, } \\
\text { ventilated } \\
(n=40)\end{array}$ & $\begin{array}{l}\text { Saline } \\
\text { Randomized crossover } \\
\text { In-line suction for both groups } \\
\text { 1. } 5 \mathrm{~mL} \text { saline } \\
\text { 2. No saline }\end{array}$ & $\begin{array}{l}\text { Statistical analysis of } \mathrm{SaO}_{2} \text { not } \\
\text { interpretable }\end{array}$ & & & \\
\hline $\begin{array}{l}\text { Hudak and } \\
\text { Bond-Domb, } \\
1996(92)\end{array}$ & $\begin{array}{l}\text { Postoperative major head } \\
\text { and neck surgery with } \\
\text { tracheotomy, nonventi- } \\
\text { lated }(\mathrm{n}=20)\end{array}$ & $\begin{array}{l}\text { Saline } \\
\text { Randomized crossover } \\
\text { 1. No saline } \\
\text { 2. } 5 \mathrm{~mL} \text { saline }\end{array}$ & $\begin{array}{l}\text { Significant difference in sputum } \\
\text { weight with saline }\end{array}$ & $P<0.02$ & $\begin{array}{l}\text { No difference in } \\
\mathrm{SaO}_{2} \\
\text { between } \\
\text { groups }\end{array}$ & NS \\
\hline $\begin{array}{c}\text { Werba et al, } \\
1993(93)\end{array}$ & $\begin{array}{l}\text { Head injury or } \\
\text { spontaneous } \\
\text { subarachnoid } \\
\text { hemorrhage, } \\
\text { ventilated }(n=18)\end{array}$ & $\begin{array}{l}\text { Drugs to reduce ICP } \\
\text { RCT } \\
\text { 1. Vecuronium }(0.12 \mathrm{mg} / \mathrm{kg}) \\
\text { 2. Atracurium }(0.4 \mathrm{mg} / \mathrm{kg})\end{array}$ & $\begin{array}{l}\text { No change in ICP for both drugs } \\
\text { Significant fall in ICP without either } \\
\text { drug }\end{array}$ & $P<0.05$ & $\begin{array}{l}\text { Diaphragmatic } \\
\text { movement } \\
\text { seen in two } \\
\text { patients in } \\
\text { both drug } \\
\text { groups }\end{array}$ & Not stated \\
\hline $\begin{array}{l}\text { White et al, } \\
1982(94)\end{array}$ & $\begin{array}{l}\text { Ventilated with brain } \\
\text { injury with ICP } \\
20 \mathrm{mmHg} \text { with } \\
\text { suctioning }(n=15)\end{array}$ & $\begin{array}{l}\text { Drugs to reduce ICP } \\
\text { Randomized crossover } \\
\text { 1. } 2 \mathrm{~mL} \text { normal saline (IV) } \\
\text { 2. } 1 \mathrm{mg} / \mathrm{kg} \text { fentanyl (IV) } \\
\text { 3. } 3 \mathrm{mg} / \mathrm{kg} \text { thiopental (IV) } \\
\text { 4. } 1.5 \mathrm{mg} / \mathrm{kg} \text { lidocaine (IV) } \\
\text { 5. } 1.5 \mathrm{mg} / \mathrm{kg} \text { lidocaine (intratracheal) } \\
6.1 \mathrm{mg} / \mathrm{kg} \text { succinylcholine (IV) }\end{array}$ & $\begin{array}{l}\text { Intratracheal lidocaine reduced peak } \\
\text { ICP with suctioning but initially } \\
\text { increased ICP } \\
\text { Succinylcholine prevented increase } \\
\text { in ICP with suctioning compared } \\
\text { with saline } \\
\text { No difference between IV lidocaine } \\
\text { and control }\end{array}$ & $P<0.01$ & $\begin{array}{l}\text { Rise in MAP } \\
\text { was similar in } \\
\text { all groups }\end{array}$ & No value \\
\hline $\begin{array}{l}\text { Donegan and } \\
\text { Bedford, } \\
1980 \text { (95) }\end{array}$ & $\begin{array}{l}\text { Ventilated head injury, } \\
\text { comatose }(n=10)\end{array}$ & $\begin{array}{l}\text { Drugs to reduce ICP } \\
\text { Randomized crossover } \\
\text { 1. Lidocaine } 2 \% \text { IV }(1.5 \mathrm{mg} / \mathrm{kg}) \\
\text { 2. Saline placebo }\end{array}$ & $\begin{array}{l}\text { Reduced ICP with lidocaine given } \\
\text { presuctioning, but both had } \\
\text { increased ICP post suctioning }\end{array}$ & $P<0.05$ & $\begin{array}{l}\text { BP increased in } \\
\text { both groups; } \\
\text { no difference } \\
\text { between } 1 \\
\text { and } 2\end{array}$ & NS \\
\hline $\begin{array}{l}\text { Brown and } \\
\text { Peeples, } \\
1992(96)\end{array}$ & $\begin{array}{l}\text { Ventilated with head } \\
\text { injury }(n=11)\end{array}$ & $\begin{array}{l}\text { Drugs to reduce ICP } \\
\text { Randomized crossover } \\
\text { 1. Hyperventilation } \\
\text { 2. IV lidocaine }(2 \%, 1.5 \mathrm{mg} / \mathrm{kg} \text {, } \\
50 \mathrm{mg} / \mathrm{min}) \\
3 . \text { Aerosolized lidocaine }(4 \% \text {, } \\
5 \mathrm{mg} / \mathrm{kg} \text { over } 15 \mathrm{~min})\end{array}$ & No difference in ICP between groups & NS & $\begin{array}{l}\text { No difference in } \\
\text { CPP between } \\
\text { groups }\end{array}$ & NS \\
\hline $\begin{array}{l}\text { Hanowell } \\
\text { et al, } 1993 \\
\text { (97) }\end{array}$ & Head injury $(n=7)$ & $\begin{array}{l}\text { Drugs to reduce ICP } \\
\text { Randomized crossover } \\
\text { 1. IV saline } \\
\text { 2. Alfentanil } 15 \mathrm{~g} / \mathrm{kg} \\
\text { 3. Alfentanil } 30 \mathrm{~g} / \mathrm{mg}\end{array}$ & $\begin{array}{l}\text { No difference in CPP between } \\
\text { groups } \\
\text { CPP decreased in combined } \\
\text { alfentanil groups versus control }\end{array}$ & $\begin{array}{c}\text { NS } \\
P<0.05\end{array}$ & $\begin{array}{l}\text { Greater } \\
\text { increase in } \\
\text { MAP with } \\
\text { combined } \\
\text { alfentanil } \\
\text { versus saline }\end{array}$ & NS \\
\hline $\begin{array}{l}\text { Winston et al, } \\
1987(98)\end{array}$ & $\begin{array}{l}\text { Pulmonary parenchymal } \\
\text { disease and sepsis, } \\
\text { ventilated }(n=6)\end{array}$ & $\begin{array}{l}\text { Drugs for bradycardia } \\
\text { Randomized crossover } \\
\text { 1. Nebulized atropine sulphate } \\
\text { ( } 0.05 \mathrm{mg} / \mathrm{kg} \text { of ideal body weight) } \\
\text { 2. Parental atropine sulphate ( } 1 \mathrm{mg} \\
\text { by IM or slow IV) } \\
\text { 3. Saline }\end{array}$ & $\begin{array}{l}\text { Bradycardia prevented with use of } \\
\text { either drug; tachycardia occurred } \\
\text { in group } 2 \text { but rarely in group } 1\end{array}$ & $P<0.001$ & & \\
\hline $\begin{array}{l}\text { Guntupalli } \\
\text { et al, } \\
1984(99)\end{array}$ & $\begin{array}{l}\text { Ventilated with jet } \\
\text { ventilator and jet tube } \\
(n=15)\end{array}$ & $\begin{array}{l}\text { Jet ventilation } \\
\text { Prospective crossover } \\
\text { 1. Suction with continuous } \\
\text { ventilation } \\
\text { 2. Stop ventilation during procedure }\end{array}$ & $\begin{array}{l}\mathrm{PaO}_{2} \text { decreased from } 417 \text { to } \\
327 \mathrm{mmHg} \text { with stopping jet }\end{array}$ & $P<0.001$ & $\begin{array}{l}\mathrm{PaCO}_{2} \\
\text { increased } \\
\text { from } 36 \text { to } \\
38 \mathrm{mmHg}\end{array}$ & $P<0.05$ \\
\hline
\end{tabular}

BP Blood pressure; bpm Beats/min; COPD Chronic obstructive pulmonary disease; CPP Cerebral perfusion pressure; ETT Endotracheal tube; FiO 2 Fractional inspired concentration of oxygen; HR Heart rate; ICP Intracranial pressure; ICU Intensive care unit; IM Intramuscular; IV Intravenous; MAP Mean arterial pressure; NS Not significant; $\mathrm{PaO}_{2}$ Arterial pressure of oxygen; PEEP Positive end-expiratory pressure; RCT Randomized controlled trial; SaO 2 Arterial oxygen saturation; $\mathrm{SpO}_{2}$ Oxygen saturation by pulse oximetry; $\mathrm{TCPO}_{2}$ Transcutaneous partial pressure of oxygen; TV Tidal volume

Insufflation: During endotracheal suctioning, insufflation catheters (usually double lumen catheters) permit oxygenenriched air to be blown into the tracheobronchial tree.

Five randomized crossover trials were identified that dealt with the technique of insufflation as a method of oxygenation (46,48-51). Three of the studies involved cardiac surgery patients (two postoperative [46,49], one intraoperative
[48]). The others involved a mixture of trauma, medical, surgical and neurological patients $(50,51)$. Double lumen insufflation catheters were used in the studies. With the exception of one study (46), all studies employed commercially available insufflation catheters. In general, insufflation resulted in maintenance of oxygen levels throughout the procedure, at flow rates of 10 to $15 \mathrm{~L} / \mathrm{min}$. 
Recommendation: The use of oxygen insufflation (at 10 to $15 \mathrm{~L} / \mathrm{min}$ flow) to maintain oxygenation is recommended for relatively stable patients who are mechanically ventilated.

Hyperinflation alone: As previously mentioned, while secretions are being removed from the tracheobronchial tree during the suctioning procedure, air is also being removed. Hypoxemia and atelectasis are among the possible harmful consequences. One manoeuvre designed to correct or reduce these effects is hyperinflation - ie, the provision of a breath or sequence of breaths at volumes greater than the usual tidal volume. Hyperinflations may be delivered with an MRB or a ventilator.

Five randomized crossover studies of hyperinflation alone involved postoperative cardiac surgery patients (52-56). The results of one study were published twice $(55,56)$ and so were combined. Two randomized crossover studies involved head-injured populations $(57,58)$. An MRB or a ventilator was used to deliver the hyperinflations in all five studies. In each case, the volumes delivered were measured and confirmed regularly by testing and calibration. Because the outcomes of interest were different, recommendations about hyperinflation for cardiac surgery patients were separated from those for head-injured patients.

The studies did not show a consistent beneficial effect of hyperinflation on oxygen levels in patients after cardiac surgery. An increase in blood pressure was observed to accompany hyperinflation. In patients with head injury, studies showed that an increase in volume (but not an increase in rate of inflation) may result in an increase in ICP. When suctioning these patients, caution should be exercised because ICP increases over time with additional suctioning sequences.

Recommendations: The use of hyperinflation delivered by any method is not recommended as a means to improve oxygenation in preoxygenated patients who undergo coronary artery bypass graft surgery. If hyperinflation is used in other populations (eg, unstable cardiac patients), caution should be employed because its use may be associated with increases in mean arterial blood pressure. Minute ventilation should be increased by rate but not volume to minimize increases in ICP in head-injured patients during suctioning.

MRB versus ventilator delivery: Several methods of delivering hyperoxygenation and/or hyperinflation to the patient during the suctioning procedure have been suggested. The MRB and ventilator are two such commonly used methods, particularly in intubated patients.

There were four randomized crossover trials $(54,59-61)$ and one comparative cohort study (62). Three of the study populations involved postoperative cardiac surgery patients $(54,60,61)$. The other studies $(59,62)$ had a mixed group of medical, surgical and trauma patients. All of the trials examined patients who were oxygenated using an MRB connected to an oxygen supply (commonly set at a flow rate of $15 \mathrm{~L} / \mathrm{min}$ ) and a ventilator delivering various volumes and fractions of inspired oxygen (commonly 100\%).
One study (54) showed no difference between the two methods, and four studies (59-62) favoured ventilatordelivered breaths to support oxygenation during suctioning. There was no difference noted between the two methods of oxygenation for arterial blood pressure in the one study that reported this outcome (54). In three of the studies (60-62), it was assumed (not confirmed by calibration) that the MRB actually delivered hyperinflations and an oxygen concentration of $100 \%$. Only two studies $(54,59)$ measured the two factors, and only one (54) controlled for these measures in the design of the trial. The reason that use of a ventilator was found to be superior to use of an MRB may be that the MRB is simply an inefficient method of breath delivery.

Recommendation: A ventilator is more effective for the delivery of oxygen than an MRB and should be used when oxygen delivery is a concern.

Use of an adaptor: Swivel adaptors with capped apertures have been an integral part of the patient ventilator circuit for many years. When opened, the aperture permits suctioning of intubated, ventilated patients without complete disconnection from the ventilator circuit. This may be advantageous in reducing the deleterious effects of endotracheal suctioning; however, suctioning through the adaptor with a conventional, disposable catheter may be technically more difficult.

Three randomized crossover trials dealt with the use of an adaptor in suctioning $(40,63,64)$. One of the studies involved postoperative cardiac surgery patients (63), another acute lung disease or acute on chronic lung disease patients (64), and one acutely ill patients with respiratory failure (40). In two reports, the type of swivel adaptor used was not identified (40,63), while one study (64) noted the use of a suction adaptor by Novametrix Medical Systems Inc, USA.

Two studies $(63,64)$ found that the use of an adaptor attenuated the change in oxygenation observed when patients are disconnected from the ventilator while being suctioned (without hyperoxygenation). The third study (40) found that suctioning through an adaptor was no different from disconnection from the ventilator with pre- and posthyperoxygenation.

Recommendation: To preserve oxygenation in mechanically ventilated medical and surgical patients, suctioning through an adaptor may be as effective as disconnecting the ventilator circuit and hyperoxygenating before and after suctioning. However, if the clinician does not have access to hyperoxygenation and/or hyperinflation, use of an adaptor is preferable to disconnection from the ventilator.

Positive end expiratory pressure adaptor: The application of positive end expiratory pressure (PEEP) to airways is a commonly used technique, particularly in acutely ventilated patients. PEEP is designed to increase functional residual capacity and enhance oxygen transport across the alveolarcapillary membrane, and is part of the management of condi- 
tions such as adult respiratory distress syndrome (ARDS) and pulmonary edema. Disconnection from the ventilator for procedures such as endotracheal suctioning disrupts the positive airway pressure being exerted. Conventional manual bagging to provide hyperinflation and/or hyperoxygenation during the technique of suctioning does not sustain the end expiratory pressures maintained by the ventilator. A modified PEEP adaptor used in conjunction with a manual MRB system has been designed to permit the maintenance of PEEP while patients are manually bagged.

One randomized crossover study (65) and one nonrandomized crossover study (66) involving use of a PEEP adaptor were identified. The first study involved a mixture of medical and surgical patients. The second focused on patients with ARDS. One study (65) found no difference in the use of a PEEP adaptor, while the other (66) reported a positive effect on $\mathrm{PaO}_{2}$. There is insufficient evidence to make a recommendation regarding the use of a PEEP adaptor in medical/surgical or ARDS patients.

Open versus closed suctioning systems: Suctioning patients on a ventilator generally requires either disconnection from the ventilator and use of a conventional disposable catheter (open), or use of a specialized closed-system suction catheter without removal from the ventilator (closed). In the closed system, the catheter is connected to a specially designed $\mathrm{T}$ piece attached to the airway. Possible benefits of the closed system include prevention of desaturation and decreased incidence of cross-contamination.

Eleven studies comparing closed with open suctioning were retrieved (67-77): three RCTs (67-69), three randomized crossover studies $(72,73,77)$, one quasirandomized, controlled trial (74) and four comparative cohort studies $(70,71,75,76)$. Studies included patients with respiratory failure, or patients following cardiac or vascular surgeries; some patients were studied during surgery.

Five studies examined the effect of open versus closed suctioning system on infection (67-71). Although some studies found a greater rate of colonization in patients with the closed suctioning system $(67,70)$, there was no difference in the rates of nosocomial pneumonia (67-69) and mortality (67). The clinical relevance of an increase in the surrogate outcome of colonization rate is unclear. All studies lacked the power to detect a difference in the incidence of pneumonia. One study examined the effect of closed versus open system on environmental spread of infection and found lower colony counts (air) with a closed system (71). The clinical relevance of this finding is not clear.

Some studies found a statistically significant difference in levels of oxygenation $(72,75,76)$, whereas others found no difference for open versus closed systems (73). When a statistically significant difference was found, the difference was not clinically important $(72,75,76)$. One small study (74) found that the closed suctioning system attenuated desaturation in ventilated patients with PEEP with greater than $10 \mathrm{~cm} \mathrm{H}_{2} \mathrm{O}$.

Only one study (77) examined the effect of closed versus open systems on secretion removal. No difference was found in the amount of secretions removed.
There is insufficient evidence on which to base a recommendation regarding the effectiveness of closed or open systems on oxygenation, secretion removal or frequency of colonization for pneumonia.

Clean versus sterile technique: The controversy continues on whether suctioning should be performed with clean or sterile technique. Clean technique involves the use of clean gloves, whereas sterile technique involves the use of sterile gloves. Only one study (78) examined clean versus sterile technique. In a retrospective comparative cohort study (chart review), infection rates were reported to be higher in the sterile than in the clean group (78). These results are questionable because of methodological problems such as lack of standardization of techniques, lack of control of confounders and use of a nonvalidated outcome tool. There is insufficient evidence on which to base a recommendation concerning clean versus sterile technique.

Straight versus Coudé catheter: Directed cannulation of either mainstem bronchus is the purpose of using a Coudé (curved) tipped catheter, particularly when it is used in intubated or tracheotomized patients. The left mainstem bronchus is more difficult to enter due to its smaller diameter and more acute angle. Failure to adequately suction the left lower lobe may result in an increased incidence of left lower lobe secretions and atelectasis (79).

Four comparative cohort studies (79-82) examined the use of straight versus Coudé catheters. Two of the studies examined the use of these catheters with anesthetized, intubated patients at the end of surgery $(80,81)$. One studied patients with tracheostomies who required fibreoptic bronchoscopy for diagnostic purposes (82), and another studied patients with either an ETT or a tracheostomy (79). The additional effect of head positioning was evaluated in two of these studies $(80,81)$.

Directed cannulation of the left mainstem bronchus was more successful in patients with a tracheostomy and with the use of a Coudé catheter (79) than with a straight catheter. The use of a curved catheter with the head in midline was also effective in cannulating the left bronchus in intubated patients after surgery (81). The investigators in one study (80) found that the straight catheter entered the left main bronchus three of 35 times regardless of the intended bronchus. This reflects the difficulty of intubating the left mainstem bronchus selectively. The Coudé catheter was somewhat more successful in cannulating the left mainstem but reached its goal less then $50 \%$ of the time. In the one study that examined the effect of the catheters on mucosal injury (82), the authors used a subjective outcome measure that made the data of limited use. There is insufficient evidence to base a recommendation on the best catheter design for the prevention of mucosal injury.

Recommendation: A curved catheter rather than a straight catheter (in tracheotomized or intubated patients) is more successful in entering the left main bronchus; however, there is no evidence as to whether suctioning the left versus the right bronchus provides an advantage to patient outcome. 
Catheter designs: Double lumen ETTs have been developed to assist with drainage of subglottic secretions and, thus, to prevent ventilator-associated pneumonia in intubated patients. Similarly, double lumen suction catheters with the additional lumen for instillation of saline have been studied.

Two RCTs examined the effectiveness of a double lumen ETT $(83,84)$ to assist with drainage of subglottic secretions. One study (83) used a design that allowed continuous aspiration of subglottic secretions (ie, below the glottis and above the cuff of the ETT) and found a decreased relative risk of pneumonia without a difference in hospital mortality. A second study (84) used a similar type of ETT but with hourly subglottic drainage via syringe and found a greater time to onset and lower incidence of nosocomial pneumonia in the group with the subglottic drainage. Further study is needed to assess the cost effectiveness of this technology and its use in high risk groups.

Recommendation: There is some evidence to support the use of modified ETT with capabilities for continuous or intermittent subglottic suctioning for the prevention of subglottic aspiration.

Three studies examined the effectiveness of double lumen catheters - two randomized crossover trials $(85,86)$ and one cohort study (87). Although one study (85) found a difference in oxygenation and suctioned volume that favoured the double lumen catheter, interpretation of the results was difficult due to the apparent lack of data for parts of the analysis. Another study (86) also reported that the dry weight of the secretions collected was greater with the double lumen catheter. In contrast, one study (87) found that that the single lumen catheter was better in terms of prevention of fall in $\mathrm{SaO}_{2}$, need to increase $\mathrm{FiO}_{2}$ and effective secretion removal. There is insufficient evidence to make a recommendation regarding the use of single versus double lumen catheters for the purpose of instillation.

Instillation of saline: Instillation of saline may loosen secretions, increase the amount of mucus plugs and secretions removed, elicit a strong cough and aid in removal of thick secretions.

Five studies (one RCT [88] and four randomized crossover studies [89-92]) assessed the effectiveness of the instillation of saline during suctioning on the recovery of secretions and on oxygenation. Four of the studies were conducted on ventilated patients (88-91) and one involved nonventilated patients with tracheostomies (92). All subjects had evidence of good gas exchange and no underlying hypoxia.

The studies compared instillation of $5 \mathrm{~mL}$ and/or $10 \mathrm{~mL}$ of saline with no saline (88-92). Most studies found no difference in oxygenation, gas exchange, heart rate or blood pressure, but an increased weight of returned secretions in the saline groups; however, the authors did not control for the added weight due to saline instillation. There is insufficient evidence on which to base recommendations regarding the use of the instillation of saline for improving oxygenation or secretion removal. There are no known detrimental effects associated with instillation. Further research is needed to examine the effectiveness of instillation in patients with marginal gas exchange; this research should control for the weight and amount of saline in the suctioned secretions.

Drugs to prevent increased ICP or CPP during suctioning: Increases in ICP as a result of suctioning may reduce cerebral perfusion and worsen ischemic insult in patients with brain injury. While sustained rises in ICP and decreases in CPP are potentially harmful, the impact of transient changes is unknown. There is no evidence to suggest that short term, acute increases in ICP or decreases in CPP during suctioning have a significant impact on neurological recovery. Various drugs are used to attenuate the rise in ICP.

One RCT (93) and four randomized crossover trials (94-97) were designed to assess the effectiveness of a variety of pharmacological agents on ICP and CPP in patients with acute head injury. The studies included patients who had severe brain injury with decreased levels of consciousness requiring ventilatory support. The interventions assessed were neuromuscular blocking agents $(93,94)$, topical and parenteral anesthetic agents (94-96), barbiturates (94) and narcotics $(94,97)$. One study assessed the effect of hyperventilation as a co-intervention (96).

The goal of neuromuscular blocking agents is muscle paralysis and, thus, the prevention of the strong muscle contractions associated with coughing during suctioning. Two studies $(93,94)$ examined the effectiveness of neuromuscular blocking agents and found that vecuronium $(0.12 \mathrm{mg} / \mathrm{kg})$, atracurium $(0.4 \mathrm{mg} / \mathrm{kg})$ and succinylcholine $(1 \mathrm{mg} / \mathrm{kg})$ during suctioning prevented the rise in ICP.

Topical and parenteral anesthetic agents are used to depress the cough response and thus prevent the associated increase in ICP. Three studies (94-96) examined the effectiveness of topical and parenteral anesthetic agents (lidocaine) and found that intravenous lidocaine $(1.5 \mathrm{mg} / \mathrm{kg}) \mathrm{had}$ no effect on ICP rise during suctioning. Intratracheal administered lidocaine $(1.5 \mathrm{mg} / \mathrm{kg})$ was more effective in suppressing the cough reflex but triggered an initial rise in ICP due to coughing caused by instillation of the fluid.

It is hypothesized that the deep sedatory effect of barbiturates prevents a rise in ICP. Only one study (94) compared thiopental $(3 \mathrm{mg} / \mathrm{kg}$ ) with saline control. This drug did not prevent a rise in ICP associated with suctioning. There is insufficient evidence to recommend the use of thiopental $(3 \mathrm{mg} / \mathrm{kg}$ ) in head-injured patients.

Finally, a rise in ICP may be prevented through the sedatory effect of narcotics. Two studies examined the effectiveness of alfentanil and fentanyl $(94,97)$. One study (97) found that alfentanil (15 g/kg and $30 \mathrm{~g} / \mathrm{kg}$ ) resulted in a decrease in CPP; in the other, fentanyl (1 $\mathrm{g} / \mathrm{kg})$ did not result in a difference in peak ICP (94). There is insufficient evidence to recommend the use of narcotics in head-injured patients. Because alfentanil may have a detrimental effect on CPP, clinicians should use caution when administering this agent. 
Recommendations: Intravenous vecuronium $(0.12 \mathrm{mg} / \mathrm{kg})$, atracurium $(0.4 \mathrm{mg} / \mathrm{kg})$ or succinylcholine $(1 \mathrm{mg} / \mathrm{kg})$ may be considered in head-injured patients to prevent an increase in ICP with suctioning. Intravenous lidocaine $(1.5 \mathrm{mg} / \mathrm{kg})$ does not appear to prevent a rise in ICP caused by coughing in head-injured patients. There may be a role for intratracheally administered lidocaine, but further investigation is needed.

Drugs to minimize or decrease the likelihood of bradycardia during suctioning: Suctioning can be complicated by bradycardia in some patients. Stimulation of vagal afferent fibres and hypoxemia has been hypothesized to be the cause of this response. A fall of greater than $20 \%$ in resting heart rate is considered significant bradycardia. Atropine sulphate is frequently used for prevention and treatment of bradycardia, and may be used in patients who exhibit this tendency during suctioning. Only one randomized crossover trial (98) assessed the ability of drugs to prevent bradycardia in ventilated patients with pulmonary parenchymal disease and sepsis that showed a $20 \%$ decrease in resting heart rate with suctioning. These investigators compared the effect of nebulized $(0.05 \mathrm{mg} / \mathrm{kg}$ ideal body weight) and parenteral ( $1 \mathrm{mg}$ by intramuscular injection or slow intravenous) atropine sulphate with a control of nebulized saline $(0.05 \mathrm{~mL} / \mathrm{kg}$ ideal body weight). Although bradycardia was prevented in all patients with either form of atropine sulphate $(\mathrm{P}<0.001)$, tachycardia occurred in all patients receiving the parenteral form. Bradycardia with suctioning is not common but may result in important clinical problems.

Recommendation: Nebulized atropine $(0.05 \mathrm{mg} / \mathrm{kg}$ ideal body weight) may prevent bradycardia in patients exhibiting a decreased heart rate with suctioning.

Jet ventilation and suctioning: Jet ventilation or high frequency jet ventilation uses smaller tidal volumes and more rapid rates than conventional ventilation. The rates are generally defined as greater than 50 breaths/min and tidal volumes less than or equal to dead space volume.

Only one small nonrandomized study examined suctioning during jet ventilation (99). $\mathrm{PaO}_{2}$ decreased when jet ventilation was discontinued during suctioning $(\mathrm{P}<0.001)$, while the partial pressure of arterial carbon dioxide increased slightly. Maintaining jet ventilation during suctioning reportedly did not affect gas exchange to the same extent. There is insufficient evidence to make a recommendation on suctioning during jet ventilation.

\section{CONCLUSIONS}

We found no literature on several suctioning procedures. For example, there were no studies on the optimum route for suctioning when the patient is not intubated (nasal versus oral); use of airway (nasal or oral); catheter size; frequency of suctioning, suction pressure, duration of suction, landmark for applying suction (ie, when resistance is encountered or af- ter the catheter has been withdrawn slightly); intermittent versus constant suction; rotation of catheter; and the use of lubrication (ie, water or gel). We did not develop evidencebased recommendations in these areas.

When examining the effectiveness of suctioning procedures, ideal outcome measures should reflect long term consequences, such as the effects of the suctioning technique on survival or the incidence of certain complications (eg, bacteremia or pneumothorax). There are inherent limitations to the use of these outcomes. For example, due to the low rate of most complications, a large sample size is needed to assess survival and the frequency of other complications. Another outcome is the effect of suctioning approaches on quality of life; however, it is difficult to measure quality of life in acutely ill patients. For these reasons, the majority of studies employed physiological outcomes that were impairment-based (such as arterial blood gases). These physiological measures may be considered surrogate measures for long term outcomes. Although a drop in oxygen saturation postsuctioning may result in higher mortality or frequency of complications, we are not aware of any studies that have examined the correlation between changes in short term physiological measures and long term outcomes. We are aware that all studies did not report on all outcomes that were measured. This was taken into account in the careful formulation of the recommendations. Because none of the studies included cost information, no information about costs is included in this guideline. The literature reviewed gave no indication of patient preferences; thus, this aspect of the guideline is also absent.

This CPG will guide interdisciplinary clinical practice when suctioning adults and children. As with any guideline, it is not designed to supplant clinical judgment in specific clinical circumstances. While there is a paucity of good quality evidence regarding many aspects of suctioning, we feel that such a synthesis of the research serves a number of purposes. First, it has focused attention on areas where there is, in fact, sufficient evidence to guide practice. Second, this effort has clearly identified many gaps in the literature, and should be used to guide future research on this topic. An update of this CPG is planned in five years. Implementation strategies have been developed to enhance the use of this guideline in practice and aid in translating the evidence into clinical practice.

ACKNOWLEDGEMENTS: Members of the Working Group express their appreciation to the following individuals for their contribution to this project: Kathy Badali, Catherine Barbeau, Corinne Berinstein, George Browman, Ian Graham, Toni Newman, Sherra Solway, Anna Tsang, and all the clinicians and experts who provided feedback on the evidence-based recommendations. The College of Nurses of Ontario and the College of Respiratory Therapists of Ontario participated with the College of Physiotherapists of Ontario to develop the CPGs. Staff representatives from the College of Physicians and Surgeons of Ontario consulted with respect to the guideline development process. The College of Physiotherapists of Ontario provided most of the financial support for this project. No funding was obtained from product manufacturers. 


\section{REFERENCES}

1. Brooks D, Solway S, Graham I, Downes L, Carter M. A survey of suctioning practices among physical therapists, respiratory therapists and nurses. Can Respir J 1999;6:513-20.

2. Barnes C, Kirchhoff K. Minimizing hypoxemia due to endotracheal suctioning: a review of the literature. Heart Lung 1986;15:164-76.

3. Mancinelli-Van Atta J, Beck S. Preventing hypoxemia and hemodynamic compromise related to endotracheal suctioning. Am J Crit Care 1992;1:62-79.

4. Hodge D. Endotracheal suctioning and the infant: a nursing care protocol to decrease complications. Neonatal Netw 1991;9:7-15.

5. Kleiber C. Clinical implications of deep and shallow suctioning in neonatal patients. Focus Crit Care 1986;13:36-9.

6. Runton N. Suctioning artificial airways in children: appropriate technique. Pediatr Nurs 1992;18:115-8.

7. Cassani VL. Hypoxemia secondary to suctioning in the neonate. Neonatal Netw 1984;2:8-16.

8. Curran J, Stanek K, Kacmarkek RM. Portable airway suction systems: a comparison of performance. Respir Care 1991;36:259-65.

9. Fiorentini A. Potential hazards of tracheobronchial suctioning. Intensive Crit Care Nurs 1992;8:217-26.

10. Stone KS. Ventilator versus manual resuscitation bag as the method for delivering hyperoxygenation before endotracheal suctioning. AACN Clin Issues Crit Care Nurs 1990:1:289-99.

11. Rosen M, Hillard EK. The effects of negative pressure during tracheal suction. Anesth Analg 1962;41:50-7.

12. Swartz K, Noonan DM, Edwards-Beckett J. A national survey of endotracheal suctioning techniques in the pediatric population. Heart Lung 1996;25:52-60.

13. Plum F, Dunning MF. Techniques for minimizing trauma to the tracheobronchial tree after tracheotomy. N Engl J Med 1956;254:193-200.

14. Canadian Nurses' Respiratory Society (CNRS) Respiratory Nursing Care Clinical Practice Guidelines. Ottawa: Canadian Lung Association, 1995.

15. Browman GP, Levine MN, Mohide A, et al. The practice guidelines development cycle: a conceptual tool for practice guidelines development and implementation. J Clin Oncol 1995;13:502-12.

16. Cohen-Addad N, Chatterjee M, Boutista N. Intrapartum suctioning of meconium: comparative efficacy of bulb syringe and DeLee catheter. J Perinatol 1987;7:111-3.

17. Locus P, Yeomans E, Crosby U. Efficacy of bulb versus DeLee suction at deliveries complicated by meconium-stained amniotic fluid. Am J Perinatol 1990;7:87-91.

18. Daga SR, Dave K, Mehta V, Pai V. Tracheal suction in meconium stained infants: a randomized controlled trial. J Trop Pediatr 1994;40:198-200.

19. Linder N, Aranda JV, Tsur M, et al. Need for endotracheal intubation and suction in meconium-stained neonates. J Pediatr 1988;112:613-5.

20. Estol PC, Piriz H, Basalo S, Simini F, Grela C. Oro-naso-pharyngeal suction at birth: effects on respiratory adaptation of normal term vaginally born infants. J Perinat Med 1992;20:297-305.

21. Barnes CA, Asonye UO, Vidyasagar D. The effects of bronchopulmonary hygiene on $\mathrm{PtcO} 2$ values in critically ill neonates. Crit Care Med 1981;9:819-22.

22. Cunningham ML, Baun MM, Nelson RM. Endotracheal suctioning of premature neonates. J Calif Perinat Assoc 1984;4:49-52.

23. Walsh CM, Bada HS, Korones SB, Carter MA, Wong SP, Arheart K. Controlled supplemental oxygenation during tracheobronchial hygiene. Nurs Res 1987;36:211-5.

24. Cabal, LA, Siassi B, Blanco C, Plajstek C, Hodgman, JE. Cardiac rate and rhythm changes during airway suctioning in premature infants with RDS. J Calif Perinat Assoc 1984;4:45-8.

25. Skov L, Ryding J, Pryds O, Greisen G. Changes in cerebral oxygenation and cerebral blood volume during endotracheal suctioning in ventilated neonates. Acta Paediatr 1992;81:389-93.

26. Wilson G, Hughes G, Rennie J, Morley C. Evaluation of two endotracheal suction regimes in babies ventilated for respiratory distress syndrome. Early Hum Dev 1991;25:87-90.

27. Fanconi S, Duc G. Intratracheal suctioning in sick preterm infants: prevention of intracranial hypertension and cerebral hypoperfusion by muscle paralysis. Pediatrics 1987;79:538-43.

28. Saarenmaa E, Huttunen P, Leppaluoto J, Fellman V. Alfentanil as procedural pain relief in newborn infants. Arch Dis Child Fetal Neonatal Ed 1996;75:F103-7.
29. Pokela ML. Pain relief can reduce hypoxemia in distressed neonates during routine treatment procedures. Pediatrics 1994;93:379-83.

30. Ninan A, O’Donnell M, Hamilton K, Tan L, Sankaran K. Physiologic changes induced by endotracheal instillation and suctioning in critically ill preterm infants with and without sedation. Am J Perinatol 1986;3:94-7.

31. Shorten DR, Byrne PJ, Jones RL. Infant responses to saline instillations and endotracheal suctioning. J Obstet Gynecol Neonatal Nurs 1991;20:464-9.

32. Beeram MR, Dhanireddy R. Effects of saline instillation during tracheal suction on lung mechanics in newborn infants. J Perinatol 1992;12:120-3

33. Gunderson LP, McPhee AJ, Donovan BF. Partially ventilated endotracheal suction. Use in newborns with respiratory distress syndrome. Am J Dis Child 1986;140:462-5.

34. Bodai BI, Briggs SW, Goldstein M, McLaughlin G, Haas A. Evaluation of the ability of $\mathrm{NeO} 2$ safe valve to minimize desaturation in neonates during suctioning. Respir Care 1989;34:355-9.

35. Zmora E, Merritt TA. Use of side-hole endotracheal tube adapter for tracheal aspiration. A controlled study. Am J Dis Child 1980;134:250-4

36. Cabal L, Devaskar S, Siassi B, et al. New endotracheal tube adaptor reducing cardiopulmonary effects of suctioning. Crit Care Med 1979;7:552-5.

37. Kerem E, Yatsiv I, Goitein KJ. Effect of endotracheal suctioning on arterial blood gases in children. Intensive Care Med 1990;16:95-9.

38. Feaster SC, West C, Ferketich S. Hyperinflation, hyperventilation, and hyperoxygenation before tracheal suctioning in children requiring long-term respiratory care. Heart Lung 1985:14:379-84.

39. Craig KC, Benson MS, Pierson DJ. Prevention of arterial oxygen desaturation during closed-airway endotracheal suction: effect of ventilator mode. Respir Care 1984;29:1013-8.

40. Brown SE, Stansbury DW, Merrill EJ, Linden GS, Light RW. Prevention of suctioning-related arterial oxygen desaturation. Comparison of off-ventilator and on-ventilator suctioning. Chest 1983;83:621-7.

41. Downes JJ, Wilson JF, Goodson D. Apnea, suction and hyperventilation: effect on arterial oxygen saturation. Anesthesiology 1961;22:29-33.

42. Belknap JD, Kirilloff LH, Zullo TG. The effect of preoxygenation technique on arterial blood gases in the mechanically ventilated patient. Nursing Subsection 1980:210. (Abst)

43. Lookinland S, Appel PL. Hemodynamic and oxygen transport changes following endotracheal suctioning in trauma patients. Nurs Res 1991:40:133-9.

44. Rogge JA, Bunde L, Baun MM. Effectiveness of oxygen concentrations of less than $100 \%$ before and after endotracheal suction in patients with chronic obstructive pulmonary disease. Heart Lung 1989;18:64-71.

45. Skelley BF, Deeren SM, Powaser MM. The effectiveness of two preoxygenation methods to prevent endotracheal suction-induced hypoxemia. Heart Lung 1980;9:316-23.

46. Langrehr EA, Washburn SC, Guthrie MP. Oxygen insufflation during endotracheal suctioning. Heart Lung 1981;10:1028-36.

47. Rudy EB, Turner BS, Baun M, Stone KS, Brucia J. Endotracheal suctioning in adults with head injury. Heart Lung 1991;20:667-74.

48. Kelly RE, Yao FS, Artusio JF Jr. Prevention of suction-induced hypoxemia by simultaneous oxygen insufflation. Crit Care Med 1987; $15: 874-5$

49. Dam V, Wild MC, Baun MM. Effect of oxygen insufflation during endotracheal suctioning on arterial pressure and oxygenation in coronary artery bypass graft patients. Am J Crit Care 1994;3:191-7.

50. Smith RM, Benson MS, Schoene RB. The efficacy of oxygen insufflation in preventing arterial oxygen desaturation during endotracheal suctioning of mechanically ventilated patients. Respir Care 1987;32:865-9.

51. Taft AA, Mishhoe SC, Dennison FH, Lain DC, Chaudhary BH. A comparison of two methods of preoxygenation during endotracheal suctioning. Respir Care 1991;36:1195-201.

52. Stone KS, Vorst EC, Lanham B, Zahn S. Effects of lung hyperinflation on mean arterial pressure and postsuctioning hypoxemia. Heart Lung 1989; 18:377-85

53. Stone KS. Ventilator versus manual resuscitation bag as the method for delivering hyperoxygenation before endotracheal suctioning. AACN Clin Issues Crit Care Nurs 1990:1:289-99.

54. Preusser BA, Stone KS, Gonyon DS, Winningham ML, Groch KF, Karl JE. Effects of two methods of preoxygenation on mean arterial pressure, cardiac output, peak airway pressure, and postsuctioning hypoxemia. Heart Lung 1988;17:290-9. 
55. Stone KS, Talaganis SAT, Preusser BA, Gonyon DS. Effect of lung hyperinflation and endotracheal suctioning on heart rate and rhythm in patients after coronary artery bypass graft surgery. Heart Lung 1991;20:443-50.

56. Stone KS, Preusser BA, Groch KF, Karl JI, Gonyon DS. The effect of lung hyperinflation and endotracheal suctioning on cardiopulmonary hemodynamics. Nurs Res 1991;40:76-80.

57. Kerr ME, Rudy EB, Weber BB, et al. Effect of short-duration hyperventilation during endotracheal suctioning on intracranial pressure in severe head-injured adults. Nurs Res 1997;46:195-201.

58. Campbell VG. Effects of controlled hyperoxygenation and endotracheal suctioning on intracranial pressure in head-injured adults. Appl Nurs Res 1991;4:138-40.

59. Grap MJ, Glass C, Corley M, Parks T. Endotracheal suctioning: ventilator vs manual delivery of hyperoxygenation breaths. Am J Crit Care 1996;5:192-7.

60. Pierce JB, Piazza DE. Differences in postsuctioning arterial blood oxygen concentration values using two postoxygenation methods. Heart Lung 1987;16:34-8.

61. Conforti C. The effect of two preoxygenation techniques in minimizing hypoxemia during endotracheal suctioning. Heart Lung 1982;11:257-8. (Abst)

62. Anderson KM. The effects of manual bagging versus mechanical ventilatory sighing on oxygenation during the suctioning procedure. Heart Lung 1989;18:301-2. (Abst)

63. Belling D, Kelley RR, Simon R. Use of the swivel adapter aperture during suctioning to prevent hypoxemia in the mechanically ventilated patient. Heart Lung 1978;7:320-2.

64. Jung RC, Newman JN. Minimizing hypoxia during endotracheal airway care. Heart Lung 1982;11:208-12.

65. Douglas S, Larson EL. The effect of a positive end-expiratory pressure adaptor on oxygenation during endotracheal suctioning. Heart Lung 1985;14:396-400.

66. Schumann L, Parsons GH. Tracheal suctioning and ventilator tubing changes in adult respiratory distress syndrome: use of a positive end-expiratory pressure valve. Heart Lung 1985;14:362-7.

67. Deppe SA, Kelly JW, Thoi LL, et al. Incidence of colonization, nosocomial pneumonia, and mortality in critically ill patients using a Trach Care closed-suction system versus an open-suction system: prospective, randomized study. Crit Care Med 1990;18:1389-93.

68. Adams DH, Hughes M, Elliott TS. Microbial colonization of closed-system suction catheters used in liver transplant patients. Intensive Crit Care Nurs 1997;13:72-6.

69. Conrad SA, George RB, Owens MW. Comparison of nosocomial pneumonia rates in closed and open tracheal suction systems. XVI World Congress Dis Chest 1996;184S. (Abst)

70. Ritz R, Scott LR, Coyle MB, Pierson DJ. Contamination of a multiple-use suction catheter in a closed-circuit system compared to contamination of a disposable, single-use suction catheter. Respir Care 1986;31:1086-91.

71. Cobley M, Atkins M, Jones PL. Environmental contamination during tracheal suction: A comparison of disposable conventional catheters with a multiple-use closed system device. Anaesthesia 1991;46:957-61.

72. Wu RS-C, Tao C-W, Wong S-Y, Tan PP-C. Use of a closed-airway suctioning system during anesthesia. Ma Tsui Hsueh Tsa Chi 1993:31:9-14.

73. Hardie DK , Kirchoff KT. A comparison of the open versus closed system of suctioning. Heart Lung 1990;19:305. (Abst)

74. Carlon GC, Fox SJ, Ackerman NJ. Evaluation of a closed-tracheal suction system. Crit Care Med 1987;15:522-5.

75. Johnson KL, Kearney PA, Johnson SB, Niblett JB, MacMillan NL, McClain RE. Closed versus open endotracheal suctioning: costs and physiologic consequences. Crit Care Med 1994;22:658-66.

76. Clark AP, Winslow EH, Tyler DO, White KM. Effects of endotracheal suctioning on mixed venous oxygen saturation and heart rate in critically ill adults. Heart Lung 1990;19:552-7.
77. Witmer MT, Hess D, Simmons M. An evaluation of the effectiveness of secretion removal with the ballard closed-circuit suction catheter. Respir Care 1991;36:844-8.

78. Harris RB, Hyman RB. Clean vs sterile tracheotomy care and level of pulmonary infection. Nurs Res 1984;33:80-5.

79. Freedman AP, Goodman L. Suctioning the left bronchial tree in the intubated adult. Crit Care Med 1982;10:43-5.

80. Kirimli B, King JE, Pfaeffle HH. Evaluation of tracheobronchial suction techniques. J Thorac Cardiovasc Surg 1970;59:340-4.

81. Kubota Y, Magaribuchi T, Ohara M, et al. Evaluation of selective bronchial suctioning in the adult. Crit Care Med 1980;8:748-9.

82. Jung RC, Gottlieb LS. Comparison of tracheobronchial suction catheters in humans. Visualization by fiberoptic bronchoscopy. Chest 1976;69:179-81.

83. Valles J, Artigas A, Rello J, et al. Continuous aspiration of subglottic secretions in preventing ventilator-associated pneumonia. Ann Intern Med 1995;122:179-86.

84. Mahul P, Auboyer C, Jospe R, et al. Prevention of nosocomial pneumonia in intubated patients: respective role of mechanical subglottic secretions drainage and stress ulcer prophylaxis. Intensive Care Med 1992;18:20-5.

85. Schmidt CH, Dusing R, Savramis A. Improved bronchial cleansing in intensive care patients with a new double-lumen catheter. Intensive Care Med 1995;21:927-32.

86. Isea JO, Poyant D, O’Donnell C, Faling LJ, Karlinsky J, Celli BR. Controlled trial of a continuous irrigation suction catheter vs conventional intermittent suction catheter in clearing bronchial secretions from ventilated patients. Chest 1993;103:1227-30.

87. Doorley PA, Durbin CG Jr, Nicholson WD. Clinical comparison of the trach care and steri-cath suction catheters. Respir Care 1990;35:1094-6. (Abst)

88. Bostick J, Wendelgass ST. Normal saline instillation as part of the suctioning procedure: effects on $\mathrm{PaO}_{2}$ and amount of secretions. Heart Lung 1987;16:532-7.

89. Gray JE, MacIntyre NR, Kronenberger WG. The effects of bolus normal saline instillation in conjunction with endotracheal suctioning. Respir Care 1990;35:785-90.

90. Ackerman MH, Gugerty B. The effect of normal saline bolus instillation in artificial airways. ORL Head Neck Nurs 1990;8:14-7.

91. Ackerman MH. The effect of saline lavage prior to suctioning. Am J Crit Care 1993;2:326-30.

92. Hudak M, Bond-Domb A. Postoperative head and neck cancer patients with artificial airways: the effect of saline lavage on tracheal mucus evacuation and oxygen saturation. ORL Head Neck Nurs 1996;14:17-21.

93. Werba A, Klezl M, Schramm W, et al. The level of neuromuscular block needed to suppress diaphragmatic movement during tracheal suction in patients with raised intracranial pressure: a study with vecuronium and atracurium. Anaesthesia 1993;48:301-3.

94. White PF, Schlobohm RM, Pitts LH, Lindauer JM. A randomized study of drugs for preventing increases in intracranial pressure during endotracheal suctioning. Anesthesiology 1982;57:242-4.

95. Donegan MF, Bedford RF. Intravenously administered lidocaine prevents intracranial hypertension during endotracheal suctioning. Anesthesiology 1980;52:516-8.

96. Brown B, Peeples D. The effects of hyperventilation and lidocaine on intracranial pressure response to endotracheal suctioning. Heart Lung 1992;21:386. (Abst)

97. Hanowell LH, Thurston JD, Behrman KH, Disbrow EA. Alfentanil administered prior to endotracheal suctioning reduces cerebral perfusion pressure. J Neurosurg Anesthesiol 1993;5:31-5.

98. Winston SJ, Gravelyn TR, Sitrin RG. Prevention of bradycardic responses to endotracheal suctioning by prior administration of nebulized atropine. Crit Care Med 1987;15:1009-11.

99. Guntupalli K, Sladen A, Klain M. High frequency jet ventilation and tracheobronchial suctioning. Crit Care Med 1984;12:791-2. 


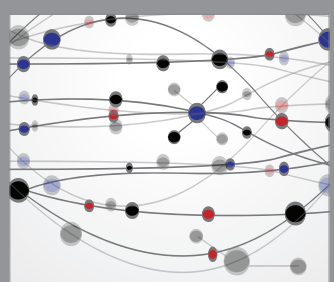

The Scientific World Journal
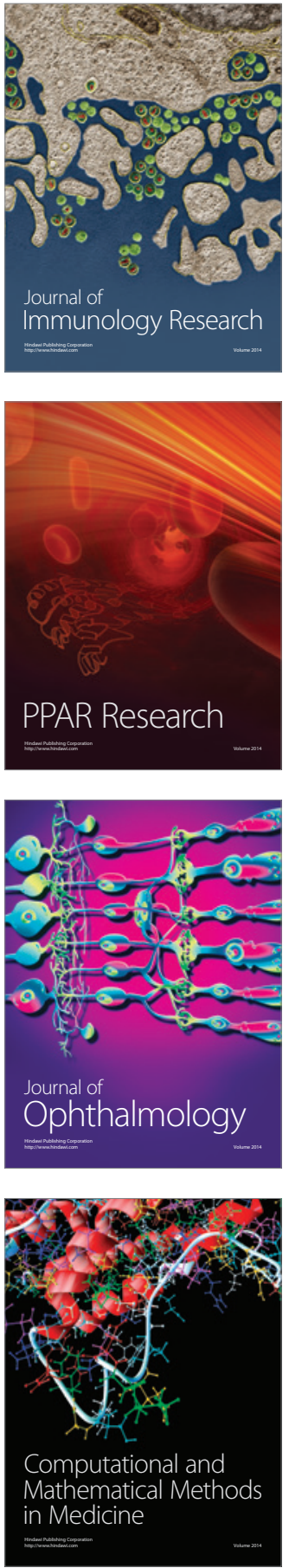

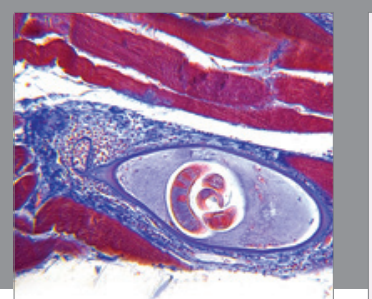

Gastroenterology Research and Practice

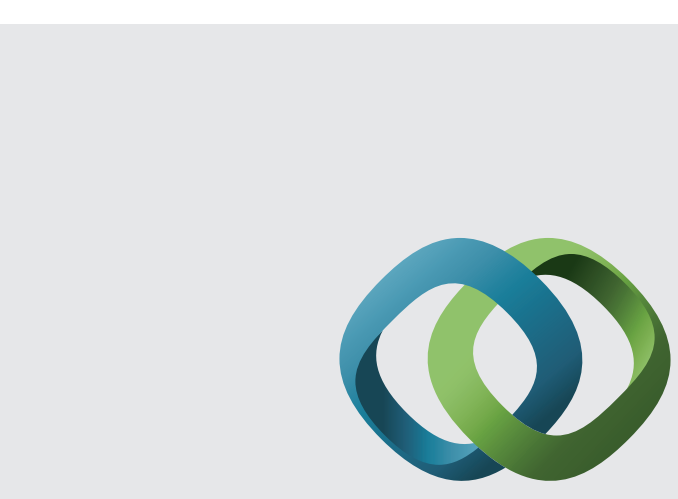

\section{Hindawi}

Submit your manuscripts at

http://www.hindawi.com
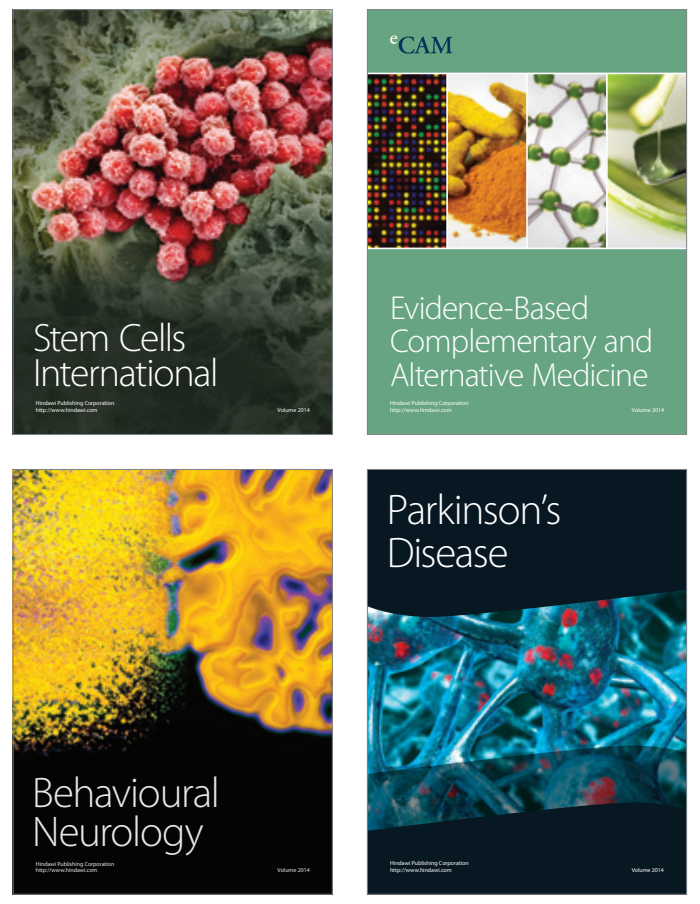
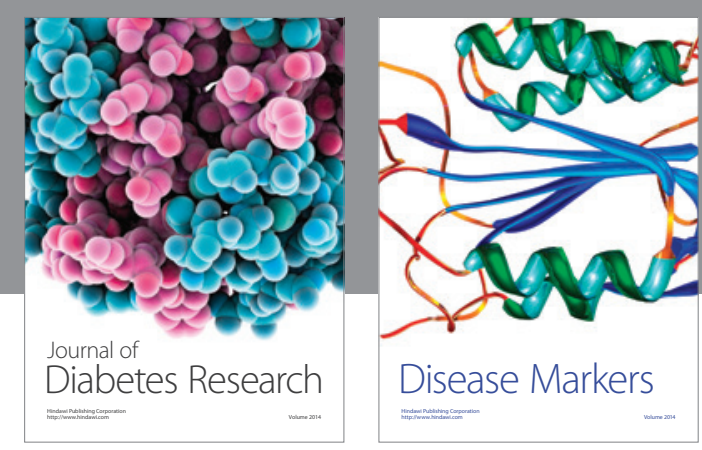

Disease Markers
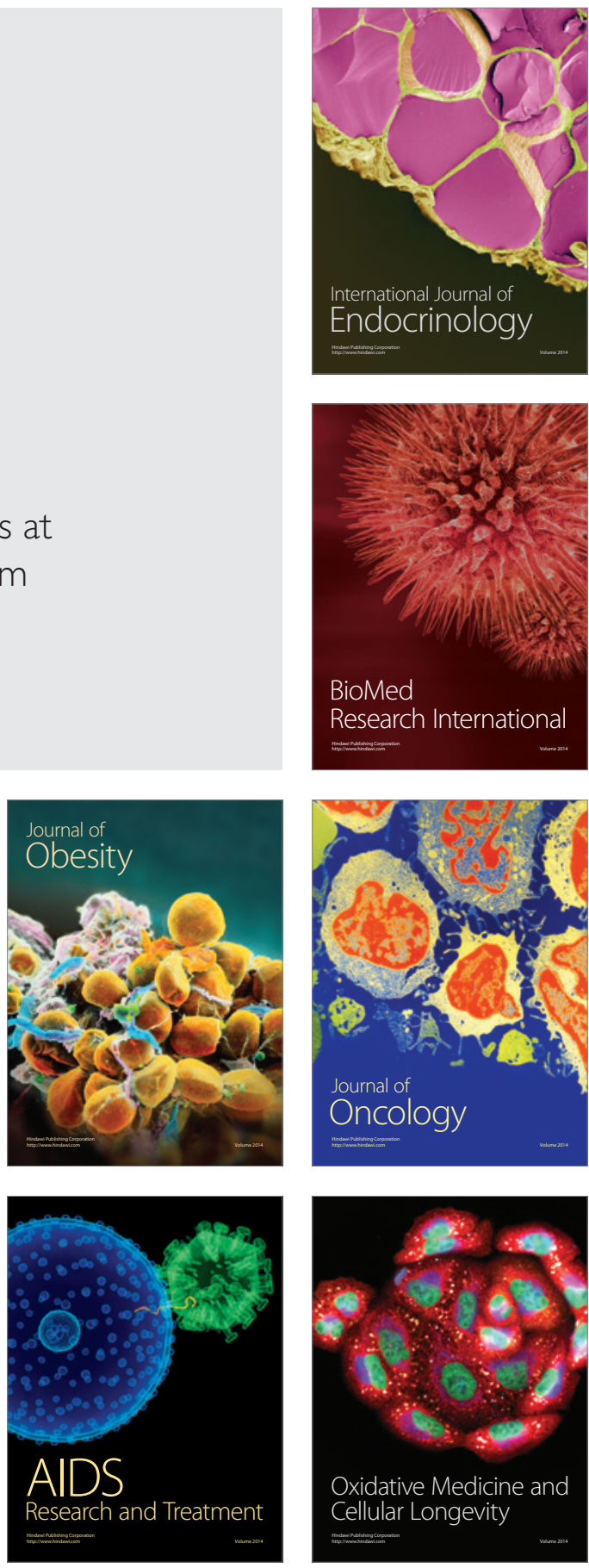